\title{
EL THOLOS DE LA PASTORA, UNA NUEVA PERSPECTIVA A PARTIR DEL ANÁLISIS ARQUEOLÓGICO DE SU CONSTRUCCIÓN
}

\section{NEW INSIGHTS INTO LA PASTORA THOLOS FROM THE ARCHAEOLOGICAL ANALYSIS OF ITS CONSTRUCTION}

\author{
JUAN MANUEL VARGAS JIMÉNEZ \\ Museo de Valencina, Centro Municipal Cívico Cultural \\ Plaza de España no 9, 41907 Valencina de la Concepción (Sevilla) \\ Telf.: 9557202 11. Correo-e: jmvargas66@gmail.com \\ LUIS MIGUEL CÁCERES PURO \\ Departamento de Ciencias de la Tierra, Universidad de Huelva \\ Correo-e: mcaceres@uhu.es. D https://orcid.org/0000-0002-1381-2476 \\ CARLOS P. ODRIOZOLA \\ Dpto. de Prehistoria y Arqueología. Universidad de Sevilla \\ UNIARQ - Centro de Arqueologia. Universidade de Lisboa \\ Correo-e: codriozola@us.es. (D) https://orcid.org/0000-0002-4411-2528
}

Resumen: El tholos de La Pastora representa la construcción más importante del "megasitio" de la Edad del Cobre de Valencia de la Concepción (Sevilla). El presente trabajo aborda su estudio desde el análisis de la información que la propia construcción en su conjunto y la de sus elementos conformantes podía contener tanto en la situación actual como en la pasada reflejadas en las fuentes antiguas. Con ello se persigue la caracterización del proceso edilicio, la reconstrucción del registro conservado y las implicaciones histórico-arqueológicas que de ello se derivan.

Se ha podido caracterizar el monumento como una construcción homogénea levantada de manera uniforme, sin faseado ni distinciones formales reconocibles. La única salvedad a lo anterior, son las interfaces recientes, fundamentalmente la asociada a la hornacina de la cámara que se realizó en época contemporánea y la referida al lugar concreto por donde se accedió en 1860. En el tramo inicial, peor conservado, se ha podido definir el sistema constructivo empleado, proponiendo una restitución de este ámbito, así como señalando el posible lugar de localización de las puntas de jabalinas.

Palabras clave: Valencina, Megalitismo, Prehistoria, Arqueología de la construcción.
Abstract: The tholos of La Pastora represents the most remarkable construction of the Copper Age megasite of Valencia de la Concepción (Seville). The present work addresses its study from the analysis of the information that the construction as a whole and its elements conform could contain both in the current situation and in the past reflected in the old sources. With this, the characterization of the building process, the reconstruction of the record that was preserved and the historical-archaeological implications derived from it are pursued.

It has been possible to characterize the monument as a homogenous construction raised in a uniform manner, without formal recognizable phase or distinctions with the exception of recent interfaces, basically associated with the niche of the chamber that was made in contemporary times or the specific place where it was accessed in 1860. In the initial section, which is the worst preserved, it has been possible to define the constructive system used, proposing a restitution of this area, as well as pointing out the possible location of the javelin tips.

Key words: Valencina, Megalithism, Prehistory, Archeology of construction.

SPAL 28.2 (2019): 113-141 


\section{INTRODUCCIÓN}

Los estudios sobre La Pastora se han centrado por lo general en revisar las fuentes antiguas que describen su descubrimiento. Estos primeros acercamientos supusieron un reconocimiento superficial de la construcción, detallado en el caso de su descubridor (Tubino 1868), o más generalistas como los posteriores insertos en obras de compendio (Gestoso 1889, Siret 1913, Leisner 1943) y en ocasiones hasta circunstanciales (Obermaier 1919). Sobre ellos se fue construyendo la imagen parcial del tholos, pues una buena parte de él aún permanecía oculta. Las excavaciones del año 1963 completaron el dibujo de la estructura al sacar a la luz el tramo inicial del corredor y la zona de entrada, sobre la que se volvió a intervenir en 1991-92, en ambos casos, actuaciones motivadas por las necesidades de protección y conservación del monumento.

En realidad, La Pastora nunca ha sido objeto de un proyecto sistemático, ni de una intervención con objetivos planteados para la resolución de los problemas empíricos que plantea. Y aunque es necesario reconocer el valor de esta información, a fecha de hoy se antoja muy limitada para comprender la verdadera dimensión alcanzada por la construcción.

Con una visión restringida al estudio de los objetos recuperados o a las necesidades más perentorias de protección, difícilmente se podrá comprender su auténtica significación histórica. Por ello nuestro interés se ha centrado en valorar el potencial de la información que las propias estructuras podían contener, no solo para la reconstrucción de los procesos que incumben al monumento sino también al entorno histórico y medioambiental en el que se inscribe (fig. 1).

Se trata de abordarlo desde una nueva perspectiva, como un verdadero memorial cultural en el que los elementos de diseño y ejecución de la construcción pueden ayudarnos, a través de su análisis, a entender su verdadera dimensión más allá de su conceptualización como un simple sepulcro y contenedor de determinados vestigios materiales (García Sanjuán 2008: 43-44).

Para ello entendimos que era pieza fundamental recurrir a la llamada arqueología de la arquitectura o análisis arqueológico de construcciones históricas (Caballero 1995: 38), dado que esta construcción no deja de ser un edificio histórico (prehistórico) con una problemática equivalente a la que se han podido enfrentar otras construcciones similares y que, por tanto, las herramientas de análisis ensayadas para aquellas bien podrían ayudarnos para el estudio constructivo de esta edificación.
La disciplina ha tenido un recorrido y una paulatina construcción especialmente fructífera para la arqueología medieval y moderna, y en nuestro ámbito, correspondiente al área metropolitana, posee muy buenos ejemplos de desarrollo metodológico y puesta en práctica sobre notables conjuntos monumentales y edificios históricos en la ciudad de Sevilla (Tabales 1997: 263-295). Para cronologías anteriores, de época romana o prerromana, las experiencias de análisis de estructuras emergentes se reducen en lógica consonancia con el menor grado de conservación de estas edificaciones y por tanto de los alzados de muros susceptibles de análisis. Y aún merman más las posibilidades si pretendemos abordar edificios de época prehistórica, pues en concreto en el III milenio a.C. en Valencina y en la práctica totalidad de los asentamientos de esta cronología, las dos únicas posibilidades de poder encontrar alzados de paramentos se restringen a unas pocas hiladas correspondientes a los zócalos de piedras de algunos fondos de cabaña y fundamentalmente, a las estructuras subterráneas conservadas bajo potentes acumulaciones artificiales de tierra. En realidad, poco o nada es posible para el caso de las cabañas, no solo por su débil consistencia sino también porque el número de casos conocidos es prácticamente irrelevante. En Valencina, en más de un centenar de intervenciones realizadas, tan solo hemos podido encontrar tres casos en los que claramente se identifica la conservación de un zócalo de piedras asociado a una cabaña: en las excavaciones de la zona deportiva municipal con dos casos (Murillo et al. 1987: 313, Ortega 2013: 126) y uno, aún inédito, localizado en el $n^{\circ} 8$ de la calle Maestro Gabriel.

Caso distinto es el de las sepulturas, donde su naturaleza subterránea y su carácter simbólico han posibilitado una mayor perdurabilidad. El empleo de materiales resistentes como la piedra, en forma de mampuestos o de grandes bloques monolíticos o la existencia de una planificación de la construcción, donde aspectos como la orientación o el diseño interior/exterior juegan un papel primordial, representan una oportunidad para este tipo de estudios, lo que, en La Pastora se hace especialmente evidente por su carácter singular, su estado de conservación y el grado de conocimiento de su espacio circundante.

Esta línea de trabajo, que trata sobre la cuestión de las arquitecturas megalíticas, tiene en la Península Ibérica sus primeros exponentes de investigación a finales de los años 90 y principios de la siguiente década. Estos primeros trabajos están circunscritos al norte peninsular y especialmente en la zona del valle del Ebro donde se comienzan a estudiar los procesos constructivos que 


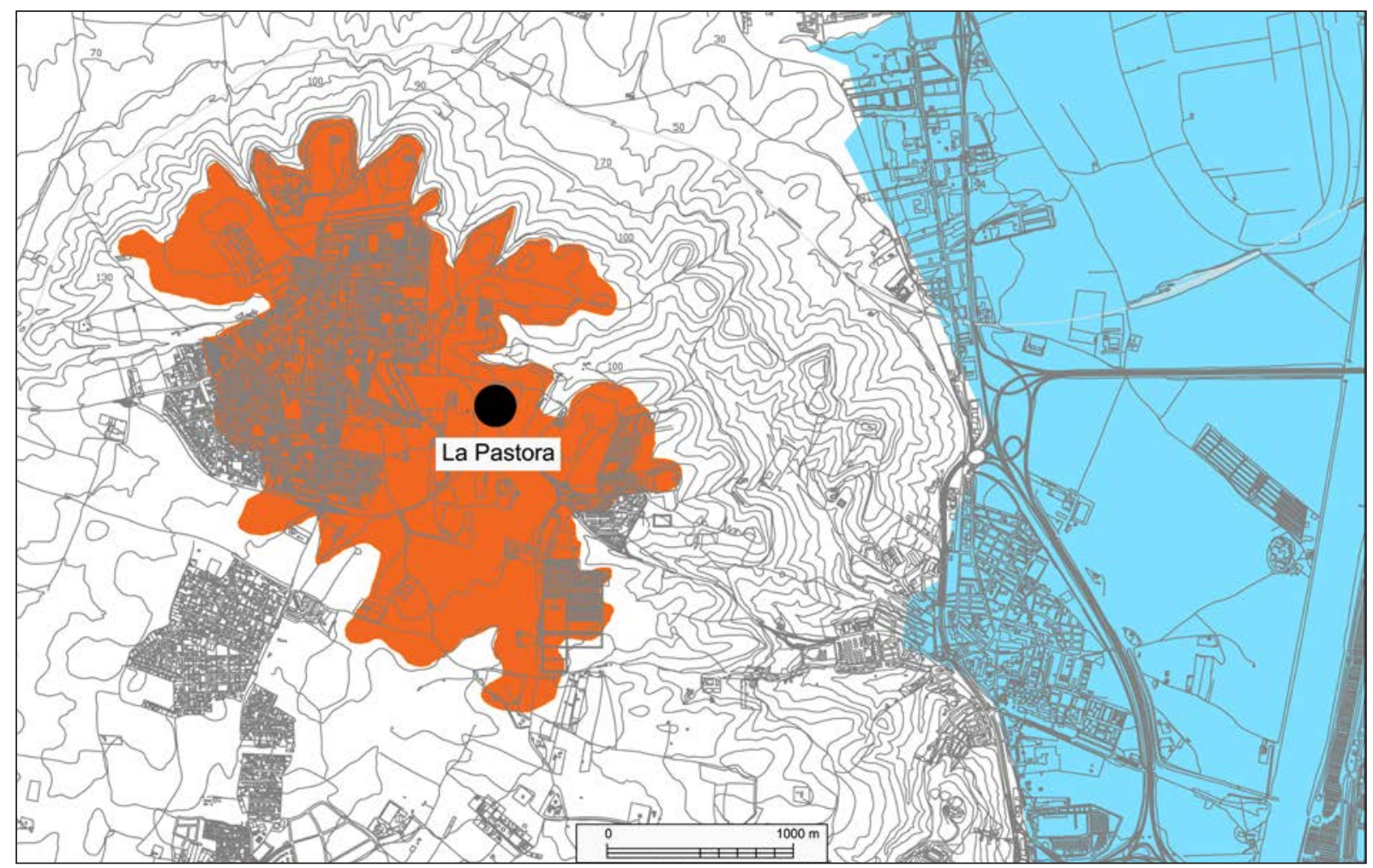

Figura 1. Localización del tholos de La Pastora dentro de la delimitación del yacimiento prehistórico de Valencina. A la derecha, entrante de mar durante el tercer milenio a.C.

incumben a estos monumentos, apareciendo las primeras sistematizaciones e interpretaciones (Tejedor 2014: 69). En un contexto de la investigación actual, en el que se enfatiza el papel de la arquitectura en el estudio de los megalitos, nuestros postulados de análisis, a través de la arqueología de la construcción, podemos considerarlos en línea con los trabajos desarrollados en diferentes conjuntos del oeste europeo (Laporte y Scarre 2016). Si bien, claro está, con determinadas particularidades y matices derivados de la propia morfología que ha preservado la construcción de La Pastora.

\section{ARQUEOLOGIA DE LA CONSTRUCCIÓN DEL THOLOS}

Las estrategias que, desde los postulados clásicos de la arqueología de la arquitectura, permiten un acercamiento detallado al proceso de evolución que concierne a un edificio histórico son: las fuentes documentales (históricas, gráficas...), la estratigrafía, la tipología (edilicia, técnica constructiva, materiales...) y finalmente las diferentes analíticas que pueden realizarse (Parenti 1988: 281).
Sin embargo, es necesario señalar algunos matices de análisis que podemos subrayar como propios en las estructuras prehistóricas. Éstas no son el resultado de una utilización continua y perdurable con sucesivas obras que conforman un conjunto constructivo fruto de la yuxtaposición y que en su totalidad singularizan al edificio histórico. Las construcciones como la que estudiamos representan un conjunto cerrado fruto de un impulso constructivo concreto y se nos muestran en el momento de clausura, cierre o abandono de la actividad que las motivó. Por ello, presentan escasa complejidad en la lectura de paramentos lo que, sin embargo, potencia su valor como indicador de los detalles técnicos del proceso constructivo que, de otro modo, no aparecerían o estarían enmascarados. Ello únicamente plantea una adaptación del método a la praxis operativa aplicable en cada caso (Pizzo 2009: 35).

De igual modo, la inexistencia de series comparativas y encasilladas, cronológica y formalmente, resta interés a la definición de los tipos de aparejo. Sin embargo, esto no disminuye el valor del estudio de la tipología constructiva que se debe orientar hacia aspectos más analíticos centrados en caracterizar los materiales 


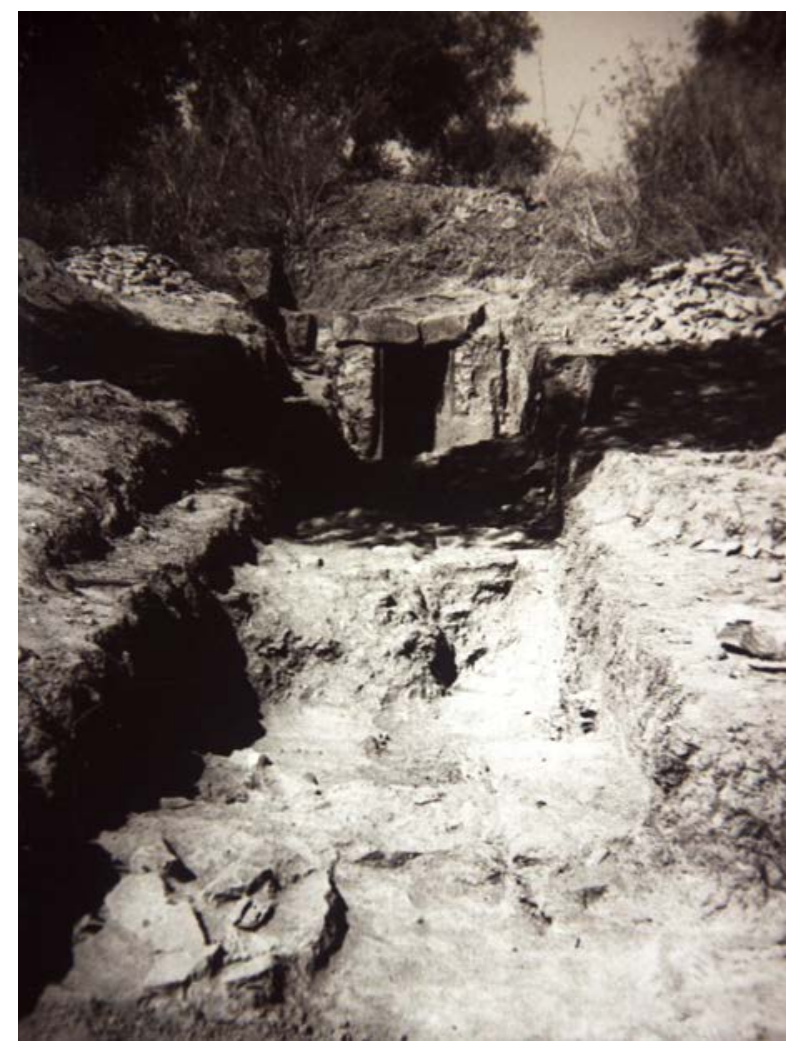

Figura 2. La Pastora al inicio de las excavaciones de 1963. Imagen procedente del Fondo Collantes, caja $\mathrm{n}^{\circ}$ 5, Dpto. de Prehistoria y Arqueología de la Universidad de Sevilla.

y las técnicas empleadas. Pues, lo restringido de estos procesos de edificación enfatizan el valor de la selección de los materiales empleados, la puesta en la obra y la tecnología empleada en su transporte y en la edificación, en especial por la complejidad referida al uso de grandes piedras. Las derivaciones en materia ambiental, económica y social son, indudablemente, más sugerentes que para el caso del uso de estos parámetros analíticos en ejemplos de edificios medievales o modernos.

Una línea que ha comenzado a dar sus frutos ha sido la investigación geoarqueológica de los materiales del monumento. Por ejemplo, la conservación en algunas losas de la cubierta del tholos de huellas de bioerosión marina ha permitido, por un lado, la datación indirecta del monumento por métodos absolutos, y por otro lado, la reconstrucción ambiental del medio de donde se extrajeron esas rocas (Cáceres et al. 2014). Se trata de una línea abierta a la que hemos incorporado nuevas muestras datadas, una más exhaustiva caracterización de los rasgos bioerosivos y los agentes causantes, un análisis y caracterización de los distintos materiales que se usaron en el monumento (Cáceres et al. 2016) y también un trabajo de rastreo de campo de las posibles áreas fuente.

\subsection{Fuentes documentales}

Dentro de las fuentes documentales se han revisado los archivos gráficos disponibles digitalizándose antiguas imágenes y planimetrías, que además han sido transformadas en archivos vectoriales para el manejo con software CAD. La referida a los textos antiguos posee un alto valor al restituir de manera descriptiva la situación en la que se encontraba la construcción al descubrirse y en los años inmediatamente posteriores a 1860. El interés que suscitó entre aquellos primeros investigadores se tradujo en descripciones o menciones más o menos detalladas en tratados hoy clásicos, de los que se pueden deducir determinados rasgos estratigráficos y de contexto, en muchos casos desaparecidos.

La serie documental se completa con la información de las dos intervenciones arqueológicas realizadas. La primera de ellas, del año 1963, lamentablemente nunca fue publicada y los datos que se pueden manejar proceden de las escuetas menciones de los arqueólogos que intervinieron (Collantes 1969: 55; Carriazo 1980: 146147), del fondo documental de Collantes depositado en el Departamento de Prehistoria y Arqueología de la Universidad de Sevilla y de los trabajos de revisión que se han ocupado de ello (Gómez de Terreros 2005: 131139, Ruiz 2013: 209-211). Su consulta nos ha deparado datos sobre la primigenia situación del primer tramo del corredor y de la zona de acceso, sobre todo a partir de las ilustrativas imágenes conservadas (fig. 2). En este sector inicial del monumento se volvió a intervenir en 1991-92 desmontándose la zona de la entrada y el inicio del corredor para posibilitar un acceso más cómodo para las visitas, lo que permitió realizar algunas precisiones sobre el primitivo acceso (Martín y Ruiz 1995: 417-420).

En la tabla 1 se resume la información estrictamente arqueológica y mayoritariamente estratigráfica que de modo claro recogen las fuentes documentales.

\subsection{Caracterización de la construcción y análisis estratigráfico}

Respecto a la caracterización constructiva, el trabajo de campo ha conllevado la realización de distintas series 
fotográficas de alta resolución para solape de sectores, obtención de panorámicas y resalte de detalles constructivos, tanto en diferentes condiciones de iluminación como con niveles de acercamiento que alcanzan hasta la microscopia. El interior de la construcción ha sido objeto de escaneo mediante tecnología láser (TLS -Terrestrial Laser Scanner) y posteriormente se ha completado y mejorado su resolución mediante la incorporación de fotogrametría. Para el exterior y mediante vuelo programado con dron se ha realizado un levantamiento 3D de toda la superficie del túmulo (fig. 4). El conjunto de la información gráfica que hemos manejado se completa con imágenes de la prospección geofísica realizada en esta parte de la finca Mataherrera - La Pastora (Vargas et al. 2012).

Todo ello combinado con levantamientos planimétricos de detalle, ha posibilitado la obtención de una nueva cartografía de mayor precisión que retoca mediciones y cálculos anteriores y permite una exhaustiva caracterización constructiva de los diferentes sectores del tholos (fig. 3).

Del cuadro general de mediciones realizadas conforme a la instrumentación antes señalada resultan los siguientes valores principales:

Longitud total del tholos: 46,96 m, medidos desde la línea de fachada al fondo interior de la cámara.

Anchura máxima/mínima de corredor: 1,04/0,76 m. Tanto el valor máximo como el mínimo se han obtenido en la zona del entorno de la puerta que separa el tramo medio y final. El máximo siempre se corresponde con la zona de contacto con la cubierta y el mínimo con el estrechamiento a media altura de los muros.

La altura del corredor se mide en la zona de contacto con la cámara, con un valor máximo de 1,81 m. Y en lo conservado, la mínima altura se constata a la entrada del tramo medio con un valor de 1,38 m.

Las losas de la cubierta se disponen formando un plano continuo que de este a oeste es perfectamente horizontal (nula pendiente).

Mientras que en el suelo las losas forman un plano inclinado con una diferencia de cota de 1 metro entre la zona más profunda de la cámara y la de la entrada, marcándose en esta distancia una pendiente del 2\%.

La cámara posee un diámetro máximo en planta de 2,60 m y conserva una altura máxima de techo a suelo de $2,42 \mathrm{~m}$.

Hay que resaltar que, frente a las anteriores planimetrías del monumento, la situación de la cámara respecto de la orientación del corredor es aún más girada hacia el sur de lo que se venía representando. De modo que en realidad aparece bastante descentrada respecto de la línea marcada por el corredor, observándose una desviación de $23^{\circ}$.

En línea con lo anterior indicar que el corredor se encuentra orientado a un acimut de $243^{\circ}$, siendo el único monumento andaluz de este tipo cuya fachada se orienta hacia la puesta de sol, por lo que se ha propuesto a la estrella Sirio como la responsable de tan excepcional orientación (Belmonte y Hoskins 2002: 98).

En lo referido a los materiales empleados en su construcción, en La Pastora, se utilizaron tres tipos de rocas, cada una de las cuales con un uso determinado. Así, las paredes están constituidas por mampuestos de cuarzoarenita de grano fino, que puede alternar con niveles lutíticos en los mismos bloques, lo que le da una textura foliada. Rocas similares han sido citadas en afloramientos paleozoicos a unos $30 \mathrm{~km}$ al norte del yacimiento. Una parte de las losas de techo son de granito, también de edad paleozoica, empleándose en la cámara y en parte del pasillo; de su análisis petrográfico se deduce una posible procedencia del batolito de la Sierra Norte de Sevilla (Cáceres et al. 2016: 368).

Finalmente, el resto de las losas de techo son de arenisca de cemento calcáreo de edad neógena. De esta última litología también son las losas del suelo, los dinteles y jambas de las puertas que dividen el corredor en los distintos sectores y los bloques que constituyen las dos últimas hiladas de la pared de la cámara. Rocas de este tipo se han localizado a unos $20 \mathrm{~km}$ al sur de Valencina como entorno más cercano. Se muestran en el campo como una alternancia rítmica de tramos limo-arcillosos y areno-areniscosos con cemento carbonatado, cuyos espesores oscilan entre 0,10-0,30 y 0,70-0,10 m respectivamente. De estos estratos de areniscas cementadas, de edad Mioceno superior y origen marino, es de donde se extrajeron las losas de este material para el tholos. Las losas muestran singulares estructuras sedimentarias y de bioturbación formadas durante su génesis en el Neógeno, algunas de las cuales se han explicado erróneamente como provenientes de la mano del hombre (cazoletas). Adicionalmente, se han documentado otras estructuras generadas por bioerosión mucho más recientes y de origen marino, de gran interés geoarqueológico (Cáceres et al. 2014).

\subsubsection{Cámara}

La cámara es sin duda el ámbito principal de toda la construcción, su diseño, los materiales empleados y la tipología constructiva son especialmente singulares. Su planta es circular y como se observa en la nueva 


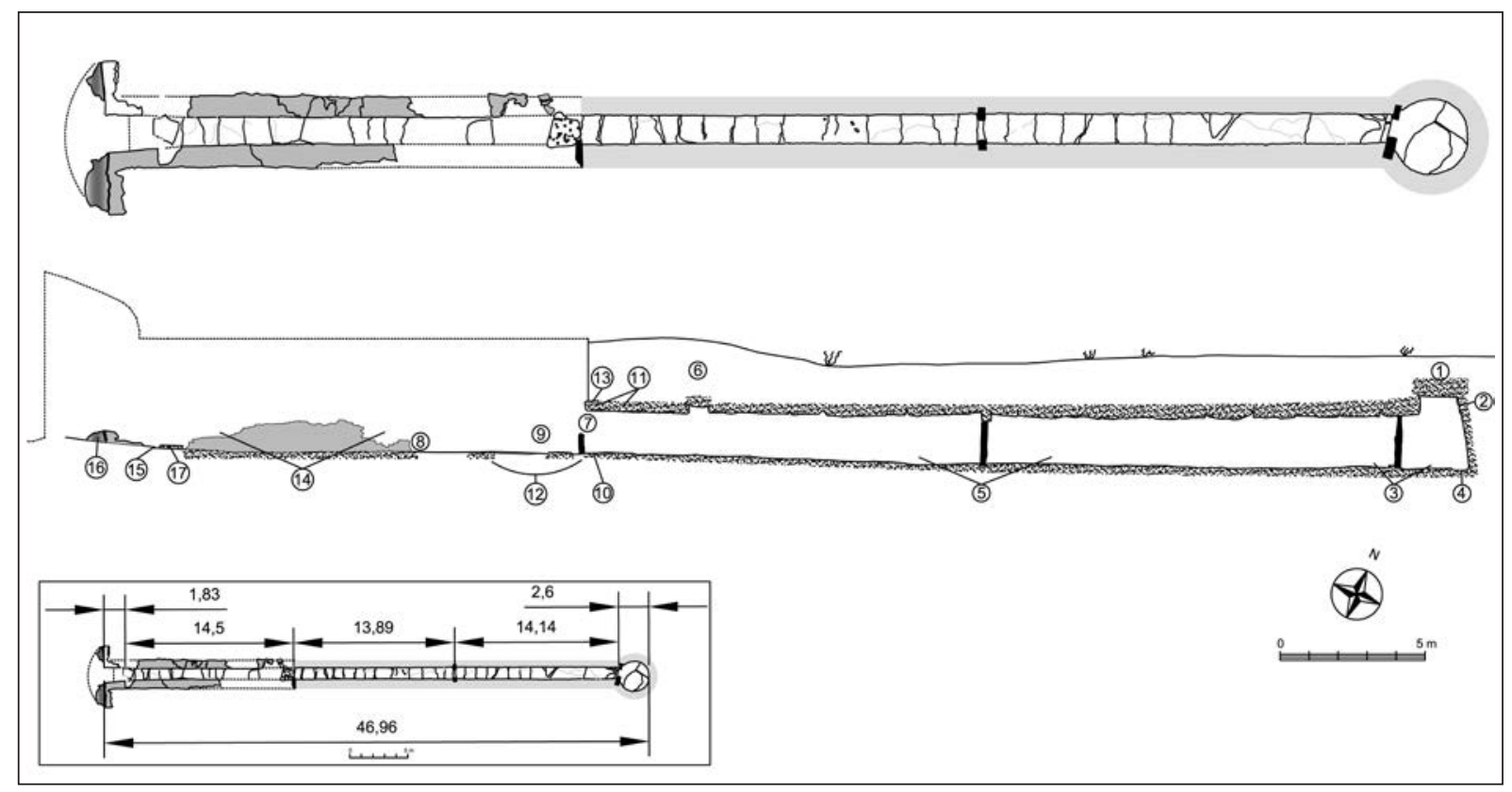

Figura 3. Planta y sección de La Pastora sobre la base de su escaneo (TLS) interior y exterior. En planta, las líneas claras son fracturas detectadas en las losas del suelo. En sección, localización de referencias arqueo-estratigráficas recogidas por las fuentes. Recuadro inferior con longitud general y por tramos de la construcción.

Tabla 1. Rasgos arqueo-estratigráficos según las fuentes documentales.

\begin{tabular}{|c|c|c|c|}
\hline $\begin{array}{c}\text { Ref. } \\
\text { Figura } 3\end{array}$ & Descripción & $\begin{array}{l}\text { Identificación de la } \\
\text { localización }\end{array}$ & Fuentes \\
\hline 1 & $\begin{array}{l}\text { Unos } 2 \text { metros de acumulación de tierras sobre la cámara medi- } \\
\text { dos por la remoción practicada. }\end{array}$ & Túmulo sobre la cámara. & Tubino 1868: 56. \\
\hline 2 & Identificación de conchas marinas entre las rocas. & Tramo superior cámara. & Tubino 1868: 55. \\
\hline 3 & Hallazgo de restos humanos. & $\begin{array}{l}\text { Cámara y zona cercana del } \\
\text { corredor (tramo final). }\end{array}$ & Candau 1894: 36 y 37. \\
\hline 4 & $\begin{array}{l}\text { Pavimento de la cámara más bajo que en el corredor (altura to- } \\
\text { tal cámara de entre 2,50 / } 3 \mathrm{~m} \text { ). }\end{array}$ & Cámara. & $\begin{array}{l}\text { Tubino 1868: } 54 . \\
\text { Cañal 1894: } 190 .\end{array}$ \\
\hline 5 & $\begin{array}{l}\text { Sobre el pavimento se acumulaban unos } 10 \mathrm{~cm} \text { de tierra (estra- } \\
\text { tigrafía interior). }\end{array}$ & $\begin{array}{l}\text { Tramos intermedio y final } \\
\text { del corredor. }\end{array}$ & Tubino 1868: 54. \\
\hline 6 & $\begin{array}{l}\text { Sobre la losa de descubrimiento se acumulaban 1-2 metros de } \\
\text { tierra. }\end{array}$ & $\begin{array}{l}\text { Tramo intermedio del co- } \\
\text { rredor. }\end{array}$ & $\begin{array}{l}\text { Tubino 1868: 52, } 54 \text { y } 56 \\
\text { Cañal 1894: } 186 \text { y } 192 .\end{array}$ \\
\hline 7 & $\begin{array}{l}\text { Excavación de un metro de galería taponada (apertura de nuevo } \\
\text { acceso). }\end{array}$ & $\begin{array}{l}\text { Zona de contacto entre el } \\
\text { tramo intermedio de corre- } \\
\text { dor y el tramo inicial. }\end{array}$ & Cañal 1894: 189. \\
\hline 8 & $\begin{array}{l}\text { Reconocimiento de la continuación de los muros laterales del } \\
\text { corredor en el tramo inicial. }\end{array}$ & $\begin{array}{l}\text { Zona de contacto entre el } \\
\text { tramo intermedio de corre- } \\
\text { dor y el tramo inicial. }\end{array}$ & $\begin{array}{l}\text { Cañal 1894: } 189 \text { y } 191 \text { (fig. 116). } \\
\text { Foto de 1963. Reproducida en } \\
\text { Gómez de Terreros 2005: 132, } \\
\text { fig. } 64 .\end{array}$ \\
\hline 9 & $\begin{array}{l}\text { En el túmulo, junto a la nueva entrada artificial (la de su descu- } \\
\text { brimiento), en la pendiente occidental, debajo de una gran losa } \\
\text { y en un recipiente cerámico se encontraron las } 30 \text { jabalinas. }\end{array}$ & $\begin{array}{l}\text { Tramo inicial del corredor } \\
\text { junto a inicio del tramo in- } \\
\text { termedio. }\end{array}$ & $\begin{array}{l}\text { Tubino 1868: } 53 \text { y } 58 . \\
\text { Gestoso 1889: } 3 . \\
\text { Cañal 1894: } 207 . \\
\text { Obermaier 1919: } 33 .\end{array}$ \\
\hline
\end{tabular}




\begin{tabular}{|c|c|c|c|}
\hline $\begin{array}{c}\text { Ref. } \\
\text { Figura } 3\end{array}$ & Descripción & $\begin{array}{l}\text { Identificación de la } \\
\text { localización }\end{array}$ & Fuentes \\
\hline 10 & Hallazgo de concha perforada (¿cuenta?) y diente humano. & $\begin{array}{l}\text { Tramo inicial del corredor } \\
\text { junto a inicio del tramo in- } \\
\text { termedio. }\end{array}$ & Cañal 1894: 206 (nota 1). \\
\hline 11 & Espesor losas de cubierta de entre 30 y 45 cm. & $\begin{array}{l}\text { Inicios tramo intermedio } \\
\text { del corredor. }\end{array}$ & $\begin{array}{l}\text { Tubino 1868: } 56 . \\
\text { Cañal 1894, } 188 .\end{array}$ \\
\hline 12 & Interfacie de destrucción hasta cota de pavimento del corredor. & $\begin{array}{l}\text { Tramo inicial en zona de } \\
\text { contacto con inicio de } \\
\text { tramo intermedio. }\end{array}$ & $\begin{array}{l}\text { Foto de 1963. Reproducida en } \\
\text { Gómez de Terreros 2005: 132, } \\
\text { fig. } 64 .\end{array}$ \\
\hline 13 & $\begin{array}{l}\text { Perforaciones circulares por bioturbación en la cara superior } \\
\text { (oculta) de losa de cubrición. }\end{array}$ & $\begin{array}{l}\text { Inicio tramo intermedio del } \\
\text { corredor. Losa } \mathrm{n}^{\circ} 1 .\end{array}$ & $\begin{array}{l}\text { Foto de 1963. Reproducida en } \\
\text { Gómez de Terreros 2005: } 134 \text {, } \\
\text { fig. } 68 .\end{array}$ \\
\hline 14 & $\begin{array}{l}\text { Sobre el pavimento se acumulaban unos } 80 \mathrm{~cm} \text { de estratigrafía } \\
\text { original (rellenos antiguos). }\end{array}$ & $\begin{array}{l}\text { Tramo inicial en su tota- } \\
\text { lidad. }\end{array}$ & $\begin{array}{l}\text { Collantes 1969: 55, Carriazo } \\
\text { 1980: 146, Fernández Chicarro } \\
\text { 1964: 101. } \\
\text { Fernández Chicarro 1974: } 2 .\end{array}$ \\
\hline 15 & $\begin{array}{l}\text { Cerramiento del inicio del corredor con losas verticales. Ortos- } \\
\text { tatos de cierre del monumento. }\end{array}$ & Tramo inicial del corredor. & Ruiz 2013: 212, fig. 8 y 9. \\
\hline 16 & $\begin{array}{l}\text { Estructura de mampuestos de clausura final de la cons- } \\
\text { trucción. Cegamiento del inicio del corredor y oculta- } \\
\text { ción de la fachada. }\end{array}$ & $\begin{array}{l}\text { Inicio corredor y fa- } \\
\text { chada. }\end{array}$ & $\begin{array}{l}\text { Carriazo 1980:146. } \\
\text { Martín y Ruiz 1995: } 418 . \\
\text { Foto de 1963. Reprodu- } \\
\text { cida en Fernández Chicarro } \\
\text { 1974: } 5 . \\
\text { Foto de 1963. Reproducida } \\
\text { en Gómez de Terreros 2005: } \\
\text { 140, fig. } 79 . \\
\text { Foto de 1991. Reproducida } \\
\text { en Vargas 2004: 100, lám. } 23 .\end{array}$ \\
\hline 17 & Presencia de grandes losas removidas de la cubierta. & $\begin{array}{l}\text { Tramo inicial. Zonas } \\
\text { exteriores, terreras ex- } \\
\text { cavación. }\end{array}$ & $\begin{array}{l}\text { Carriazo 1980: } 146 \text { y } 147 . \\
\text { Fotos de 1963. Reproducidas } \\
\text { en Goméz de Terreros 2005: } \\
\text { 135-136, figs. 70-75, 138, } \\
\text { fig., 140, fig. } 78 . \\
\text { Foto de 1991. Reproducida } \\
\text { en Vargas 2004: 100, lám. } 23 .\end{array}$ \\
\hline
\end{tabular}

cartografía, está ligeramente descentrada hacia el sur. La sección se estrecha de suelo a techo desde los 2,60 $\mathrm{m}$ de la base hasta cerrar un círculo de $2 \mathrm{~m}$ de diámetro en la zona superior.

La cubierta está constituida por un gran bloque monolítico de granito que mediante la paulatina aproximación de las hiladas de mampuestos logra repartir más homogéneamente los empujes superiores de esa gran losa.

El paramento circular de la cámara muestra un doble tipo de aparejo. En la parte más alta una banda de dos hiladas de bloques de arenisca sirve de sustento directo al gran monolito de la cubierta. Y en el resto una fábrica de mampuestos de cuarzoarenita que, aunque sigue la norma del resto del monumento, muestra ciertos elementos diferenciadores.

En la parte superior los bloques de arenisca muestran formas irregulares alargadas trapezoidales o tendentes a rectangular. La longitud de las caras visibles es variable predominando los grandes bloques de entre 60 y $80 \mathrm{~cm}$ de longitud y un grosor de $20-30 \mathrm{~cm}$. Se disponen a soga en hiladas horizontales, incluso por encima de la primera losa que cubre el inicio del corredor. A tramos muestran lajas de cuarzoarenita a modo de cuñas de nivelación. Las juntas horizontales entre hiladas (tendeles) tienen una media de separación de entre 2 y $5 \mathrm{~cm}$, mientras que, en las verticales, situadas de forma 


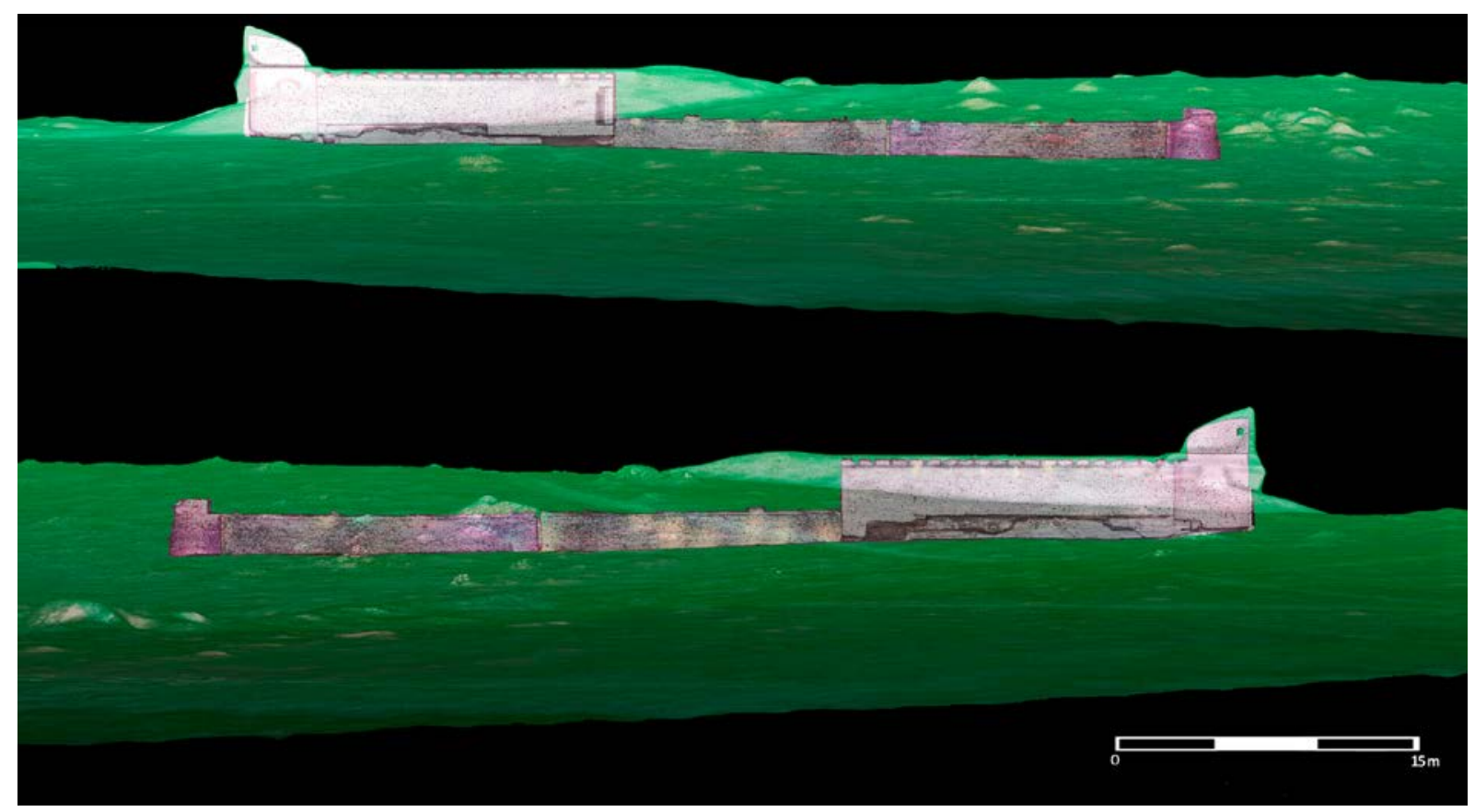

Figura 4. Imagen obtenida del escaneo-fotografiado HD del interior del monumento y modelado 3D del exterior. Fotografía HD y procesado por Rubén Parrilla, escaneado del monumento por Eweer Ingeniería Laser S.L.

salteada, la media de separación entre los mampuestos es de 1-2 cm. Pequeños fragmentos de lajas calzando los mampuestos y un relleno de tonalidad marronácea y textura arcillosa ocupan el interior de los intersticios. En el lado sur varios de los bloques superiores muestran la presencia de una colonia de ostreidos adheridos a su parte inferior. Para el acabado exterior se escogen las caras más regulares que además presentan una significativa coloración roja intensa, singular rasgo que se ha comprobado ausente en lo observado del resto de las caras de cada uno de los bloques.

Por debajo de esta fábrica se dispone un aparejo irregular de mampostería de bloques de cuarzoarenita exfoliados trapezoidales y mayoritariamente alargados dispuestos a tizón hacia el exterior y con cuñas de pequeñas lajas de nivelación. Presenta la siguiente caracterización constructiva:

- Mampuestos por $\mathrm{m}^{2}$ : 70 unidades.

- Forma/tamaño de mampuestos: Tamaño irregular de formas trapezoidales alargadas con caras tendentes a planas, en mayor medida la cara vista. Conforme a las caras visibles, existe un predominio del formato de 30-39 cm de longitud con una anchura de entre 5 y $8 \mathrm{~cm}$. Los restantes más pequeños se sitúan entre 15 y $20 \mathrm{~cm}$ de longitud con anchuras que rara vez superan los $5 \mathrm{~cm}$.
- Disposición de los mampuestos: Se disponen a tizón hacia el exterior con las caras planas y regulares (careadas) formando hiladas horizontales o tendentes a la horizontalidad que se elevan ligeramente en la zona de contacto con las jambas de separación del corredor, lo que indica una adaptación a dicho límite y por tanto una relación estratigráfica posterior a la colocación de las jambas.

- Máximo de hiladas: 27.

- Intersticios o juntas: Las horizontales entre hiladas (tendeles) muestran poco o nula separación, con casos en los que los mampuestos están “a seco” o con un escaso centímetro de separación respecto de la hilada superior o inferior. Las juntas verticales se sitúan de forma salteada entre hiladas y muestran también una escasa separación con media de $1 \mathrm{~cm}$ escaso. Se detectan algunos pequeños fragmentos de lajas calzando los mampuestos y en algún punto con alguna perdida un relleno interior muy fino y depurado de tonalidad marronácea y textura arcillosa.

Acabado: La selección de determinadas características naturales de los bloques de cuarzoarenita en cantera y su colocación a vista en la cámara logran generar un aspecto de acabado exterior de una singular coloración rojizo-parduzca que en algunas piezas además se ve realzado por la presencia 


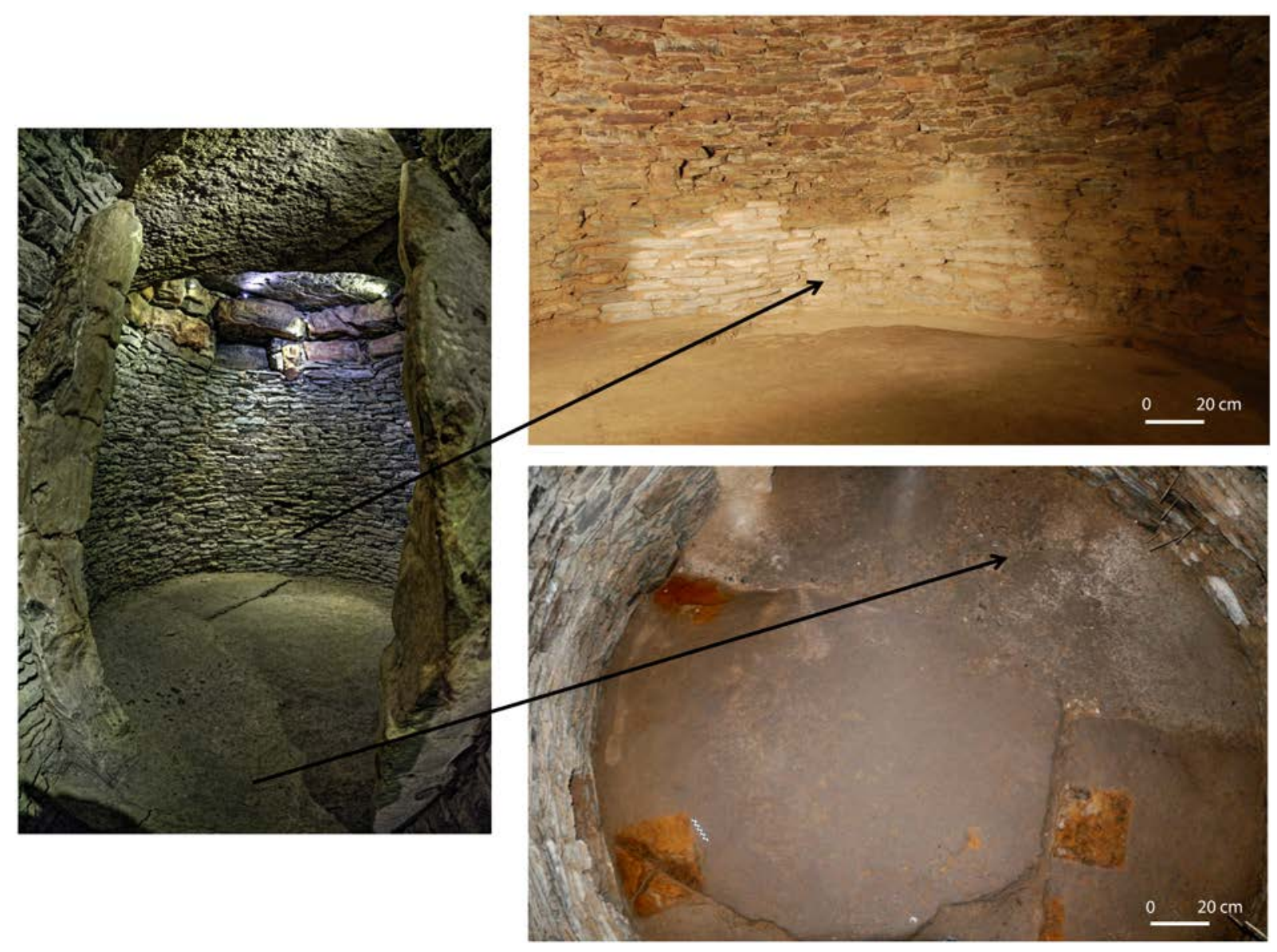

Figura 5. Interfaces de reparación en muro y pavimento de la cámara.

en superficie de cristales de cuarzo planos adheridos. Estos cristales no son más que venas de cuarzo que, en el afloramiento original, rellenaban algunas fracturas o diaclasas. A lo largo de dichas discontinuidades, con o sin relleno cuarcítico, se separan preferentemente los bloques de mampuesto de forma natural o artificial con relativo poco esfuerzo (Cáceres et al. 2016).

- Conservación/Patologías: Disgregación constructiva por exfoliado de alguna laja y perdida puntual de bloques de pequeño tamaño. Perdidas parciales de los acabados antes señalados por fricción y rozamiento.

Las dimensiones de los bloques y la práctica ausencia de llagueado otorgan un aspecto de fuerte compactación y solidez al conjunto resultante. Frente a ello, se distinguen varios tramos con interfaces de rotura y posterior reposición.

Por un lado, la parte baja del paramento muestra una fábrica de pequeños mampuestos no careados, disposición aleatoria sin conformar hiladas continuas, pequeño formato de los mampuestos (entorno a los 10 cm de longitud y $2 \mathrm{~cm}$ de anchura) y presencia de un relleno interior marronáceo que enrasa las juntas. La reposición realizada además busca la verticalidad del tramo sin respetar la técnica de aproximación de hiladas (fig. 5).

Por otro y adosada a la jamba sur, se aprecia una fábrica de suelo a techo que junto a mayoritarias cuarzoarenitas emplea algún bloque de arenisca y caliza de gran tamaño y sin careado. Esta reposición muestra una cuidada factura con presencia de un compacto mortero blanquecino y una adaptación a la curvatura de la aproximación de hiladas original.

Como singularidad mencionar la presencia de una hornacina realizada en la franja correspondiente a los bloques superiores de arenisca. La parte superior está coronada por uno de los grandes bloques de arenisca, la inferior la forma una somera repisa de dos lajas horizontales de cuarzoarenita, en los laterales sendos 
bloques de arenisca - uno de ellos girado y colocado en vertical- son recalzados por pequeñas lajas horizontales y finalmente el fondo también aparece ocupado por otro gran bloque de arenisca. En las juntas se aprecia un compacto mortero de color grisáceo y textura arenosa. Del análisis estratigráfico se deduce que su realización supone una interfaz de rotura de la fábrica original, evidenciándose el desplazamiento y la recolocación de bloques y lajas, así como el empleo de un claro mortero de sujeción que evidencian su cronología reciente.

En el pavimento de la cámara hemos podido detectar también intervenciones posteriores al documentar la existencia de vacíos y morteros recientes elaborados con cemento. Efectivamente, ha sido posible distinguir tres sectores, el primero conserva en la zona central tres losas originales de arenisca, el segundo, en el fondo sureste, forma un escalón que da paso a un relleno inferior de tierra, y finalmente el tercero, a la entrada de la cámara y ocupando todo el cuadrante noroeste muestra un relleno con mortero de gravas y cemento que alcanza y supera la cota de las losas de arenisca. Los puntos de contacto con las reposiciones del muro y los solapamientos observables plantean como las propias losas de arenisca probablemente también fueron objeto de remoción y posterior recolocación. De modo que podemos concluir como a nivel estratigráfico el pavimento actual de la cámara del tholos no se corresponde con su situación original, lo que por otra parte concuerda con la discrepancia de cotas detectada entre lo recogido por las fuentes antiguas y las mediciones actuales. La mayor profundidad del suelo de la cámara recogida por Tubino, se ha tornado justamente en la situación contraria y ello por las remociones, rellenos y recolocaciones que han elevado la actual cota de pavimento (fig. 5).

\subsubsection{Corredor}

El corredor muestra en su totalidad una longitud de 44,36 m y una anchura variable debido a la ligera inclinación que muestran los muros laterales, paulatinamente mayor de techo a suelo. Es por ello que la sección presenta forma de trapecio isósceles con laterales que en algunos sectores se muestran ligeramente convexos. Se divide en tres tramos marcados por losas sobresalientes de arenisca que a modo de puertas compartimentan su recorrido. Denominamos tramo final al colindante con la cámara, tramo intermedio al central y finalmente tramo inicial al que desemboca en la fachada exterior del monumento.

\subsubsection{Tramo final del corredor}

El tramo final del corredor comienza, en el extremo este con dos jambas sobre las que apoya una gran losa de granito ( ${ }^{\circ} 26$ en fig. 6) que en gran parte se introduce hacia el interior de la propia cámara circular. Esta circunstancia determina la existencia de una secuencia estratigráfica vertical en la que se enlazan las relaciones entre los elementos de la cámara y el corredor, resultando como: en primer lugar, la construcción se inició con la colocación de estas jambas monolíticas de arenisca a modo de pilares laterales, simultánea o ligeramente posterior se levanta el muro de cuarzoarenita que le da cobertura lateral. Sobre ellos se coloca el gran bloque de granito $n^{\circ} 26$ y con posterioridad se termina el muro de la cámara, que habíamos visto como en este sector se adapta a la jamba previa. En la propia cámara se continúa con la ejecución del tramo superior de grandes bloques de arenisca que vemos como se superpone a la losa $n^{\circ} 26$ y finalmente se coloca la gran losa de la cubierta ( $\left.\mathrm{n}^{\circ} 27\right)$. Ello otorga un papel primordial a estos salientes monolíticos pues se constata su situación en el inicio de la secuencia constructiva y su significación estructural y de diseño premeditado por su funcionamiento como soportes maestros de la construcción de muros y cubierta (fig. 6).

A partir de este punto la cubierta se desarrolla con una alternancia de losas de granito y areniscas (números del 26 al 19) hasta alcanzar la mitad de este tramo final, siendo las restantes de la mitad oeste exclusivamente de arenisca (números del 18 al 15). Salvo en la primera que se introduce en el círculo de la cámara con dos frentes claramente perfilados, en ninguna otra son apreciables labores de cantería. Sin embargo, los laterales se ajustan muy finamente entre bloques denotando una selección y colocación no aleatoria. En lo observable desde el interior del tholos, las formas de las losas son alargadas trapezoidales o tendentes a rectangulares con frentes regulares y las caras vistas uniformes, pero con las irregularidades propias de su origen, por tanto, sin apariencia de tratamiento o acabado alguno de origen antrópico. Las anchuras no son homogéneas y oscilan entre un máximo marcado por los 1,65 m del bloque $\mathrm{n}^{\circ} 24$ y el mínimo medido en el $\mathrm{n}^{\circ} 20$ con 0,75 $\mathrm{m}$; y en cuanto al espesor los huecos dejados por alguna de las uniones permiten medir grosores superiores a los $20 \mathrm{~cm}$, salvo la $\mathrm{n}^{\circ} 13$ con un espesor variable de 20 a $13 \mathrm{~cm}$ (hacia el este). Existe además una tendencia a ser más gruesas hacia la cámara, pues a partir de la 18 los espesores superan los $30 \mathrm{~cm}$, culminando en la 26 con $46 \mathrm{~cm}$. 


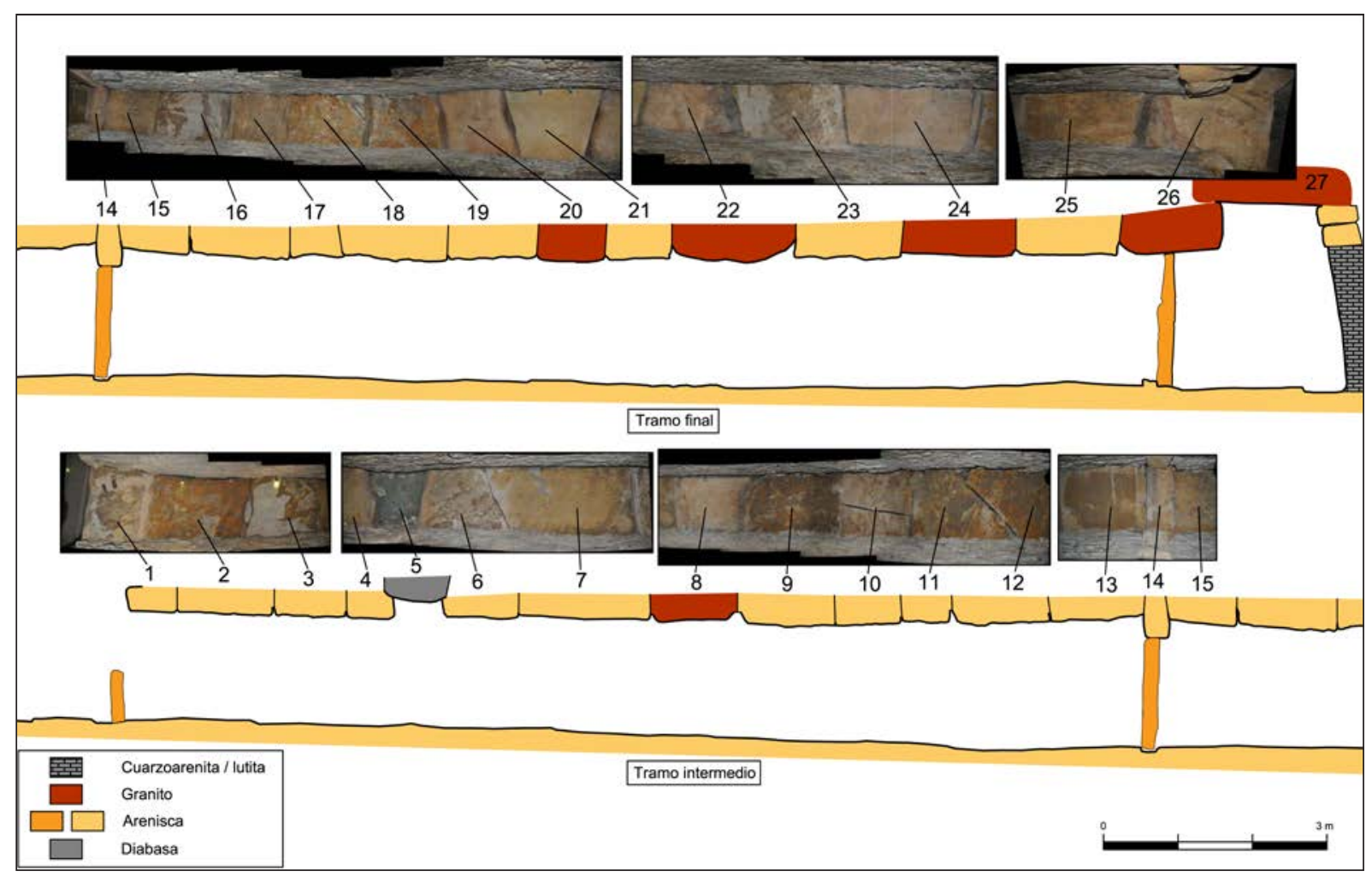

Figura 6. Sección de los tramos final e intermedio del corredor con referencias de la cubierta de losas.

Todas las areniscas de la cubierta y también las jambas laterales muestran perforaciones circulares que hemos podido determinar como de origen claramente natural y originadas por actividad orgánica propia del medio litoral del que se extrajeron (bioerosión). También se observan en gran parte de estas rocas otras estructuras más antiguas, resultado de la actividad biológica durante el depósito de las arenas que configuraron esta litología en el Terciario (bioturbación). Especialmente las losas de la cubierta $n^{0} 17$ y 15 muestran una notable concentración de pequeñas oquedades bioerosivas ocupadas por bivalvos de origen marino que alfombran toda la superficie de su cara vista, otorgándole una singular percepción de moteado blanquecino que al contrastar con los tonos marronáceos de la matriz rocosa generan un singular efecto visual.

Sobre la base del muestreo y el estudio de esta fauna generadora de las oquedades, hemos podido plantear una línea de investigación relativa al ambiente y a la datación del momento de su extracción, posibilitando con ello una datación indirecta de la construcción del monumento (Cáceres et al. 2014).

En las losas 18 y 19 se ha detectado otra particularidad, en este caso relacionada con las patologías constructivas. Se trata de una grieta oblicua de tendencia rectilínea que recorre ambos bloques prolongándose por debajo de los muros. Posee una anchura media de 1 cm que en su extremo norte se agranda por la presencia de algún desprendimiento parcial.

Los paramentos norte y sur de este tramo final presentan morfologías similares. Se trata de un aparejo irregular de mampostería de bloques de cuarzoarenita exfoliados, trapezoidales y mayoritariamente alargados y dispuestos a tizón hacia el exterior y con cuñas de pequeñas lajas de nivelación que muestra la siguiente caracterización:

— Mampuestos por $\mathrm{m}^{2}$ : 105 unidades.

- Forma/tamaño de mampuestos: Tamaño irregular de formas trapezoidales alargadas con caras tendentes a planas, en mayor medida la cara vista. Conforme a las caras visibles, existe un predominio del formato de $15-25 \mathrm{~cm}$ de longitud con una anchura de entre 6 y $2 \mathrm{~cm}$, con algunas piezas de mayor tamaño agrupadas en hiladas diferenciadas que muestran valores de entre 39 y $48 \mathrm{~cm}$ con un grosor de entre 5 y $8 \mathrm{~cm}$.

- Disposición de los mampuestos: Mayoritariamente se disponen a tizón hacia el exterior con las caras 
planas y regulares (careadas) formando hiladas horizontales o tendentes a la horizontalidad. Singularizar como en la mitad oriental de los paramentos se observa la disposición de dos hiladas localizadas a una altura intermedia entre la cubierta y el suelo, que muestra los mampuestos de mayor tamaño y colocados a soga con algún tramo doble en el que se solapan dos piezas.

- Máximo de hiladas: 27.

— Intersticios o juntas: Las horizontales entre hiladas (tendeles) muestran poco o nula separación, con mampuestos que están “a seco” o por debajo de 1 cm de separación respecto de la hilada superior o inferior. Las juntas verticales se sitúan de forma salteada entre hiladas no homogéneamente y con muy escasa separación, también por debajo de $1 \mathrm{~cm}$. Se detectan fragmentos de lajas calzando algunos mampuestos.

Acabado: No se aprecia evidencia alguna de acabado externo, más allá del propio careado de los mampuestos que conforman un plano exterior más o menos regular.

- Conservación/patologías: Fracturas de bloques por presión superior, disgregación por exfoliado horizontal de origen natural y perdidas puntuales de algunas piezas pequeñas. En las hiladas inferiores más cercanas al pavimento se muestra un mayoritario desgaste del careado de los bloques, con desaparición de las superficies planas y alteración de las juntas tanto horizontales como verticales, motivado por el desgaste por fricción que han sufrido al ser la zona mayormente expuesta a los agentes antrópicos, tanto durante los procesos de excavación antiguos como actualmente durante las visitas al monumento.

Desde un punto de constructivo y en su conjunto, esta fábrica es homogénea y compacta sin que se hayan detectado interfaces estratigráficas. Únicamente hay que resaltar, por su valor como indicador del proceso de edificación, la presencia de dos hiladas con tramos dobles de mampuestos que, dispuestas a soga, escapan a la norma general del aparejo a tizón. Su localización en el extremo oriental en la zona de contacto con la cámara, donde además existe una mayor altura de los muros, justifica su empleo como elemento estructural de nivelación para un mejor soporte del proceso de construcción en altura, y por ello mismo, a medida que disminuye esa altura en el corredor se hace menos necesaria, desapareciendo, por tanto, del registro estratigráfico paramental restante.
Para los mampuestos y a partir de este punto, vemos como se recurre a piezas más pequeñas que las empleadas en el revestimiento de la cámara, resaltando por tanto la esmerada selección del material que se realizó. Ello además y como veremos a continuación, será norma en el resto de los tramos del corredor donde el tamaño medio de los mampuestos siempre es menor.

El pavimento de este tramo final $-\mathrm{y}$ de todo el corredor en general- presenta problemas de conservación que dificultan la identificación y definición de los elementos que lo conforman. Comienza con un escalón de piedra que se adosa al exterior oeste de las jambas de separación con la cámara. A partir de este punto se disponen grandes bloques de piedra que en la actualidad se muestran con formas desdibujadas y poco precisas. En total se han podido identificar al menos 15 losas que en algunos casos muestran oquedades superficiales que, como en el caso de la cubierta, podemos vincular con elementos naturales fruto de la actividad biológica marina. También se ha identificado algún caso de abombamiento central y de fractura transversal con elevación del borde resultante.

\subsubsection{Tramo intermedio del corredor}

El tramo intermedio queda comprendido entre las dos compartimentaciones centrales realizadas con monolitos verticales de piedra arenisca. La más oriental posee dos jambas laterales que sostienen un dintel (losa $\mathrm{n}^{\circ} 14$ en fig. 6), también sobresaliente hacia el interior del corredor. Estratigráficamente el dintel no da soporte a las losas de la cubierta, como en el caso de las jambas de la cámara, sino que se introduce en los rellenos superiores dejando a éstas únicamente en contacto con su lateral; es pues, un elemento previo y sin valor estructural respecto del sostenimiento de la cubrición. En el otro extremo del corredor únicamente se ha conservado la losa fragmentada de una de las jambas laterales, si bien los antiguos trabajos de excavación constataron la aparición de la fosa correspondiente a la otra gemela (Martin y Ruiz 1995: 418). El diferente plano de alineación vertical entre las jambas y el remate final de la última losa de cubrición señalaría una seriación estratigráfica como la descrita para el caso anterior, con las losas de la cubierta adosadas, no apoyadas, en las jambas (fig. 6).

La cubierta muestra una presencia mayoritaria de losas de areniscas (números 1, 2, 3, 4, 6, 7, 9, 10, 11, 12 y 13) con un solo caso de granito $\left(n^{\circ} 8\right)$ y una diabasa ( $\mathrm{n}^{\circ}$ ), esta última colocada en un plano superior y apoyada sobre las losas anterior y posterior. Las formas de las losas son alargadas trapezoidales o tendentes 


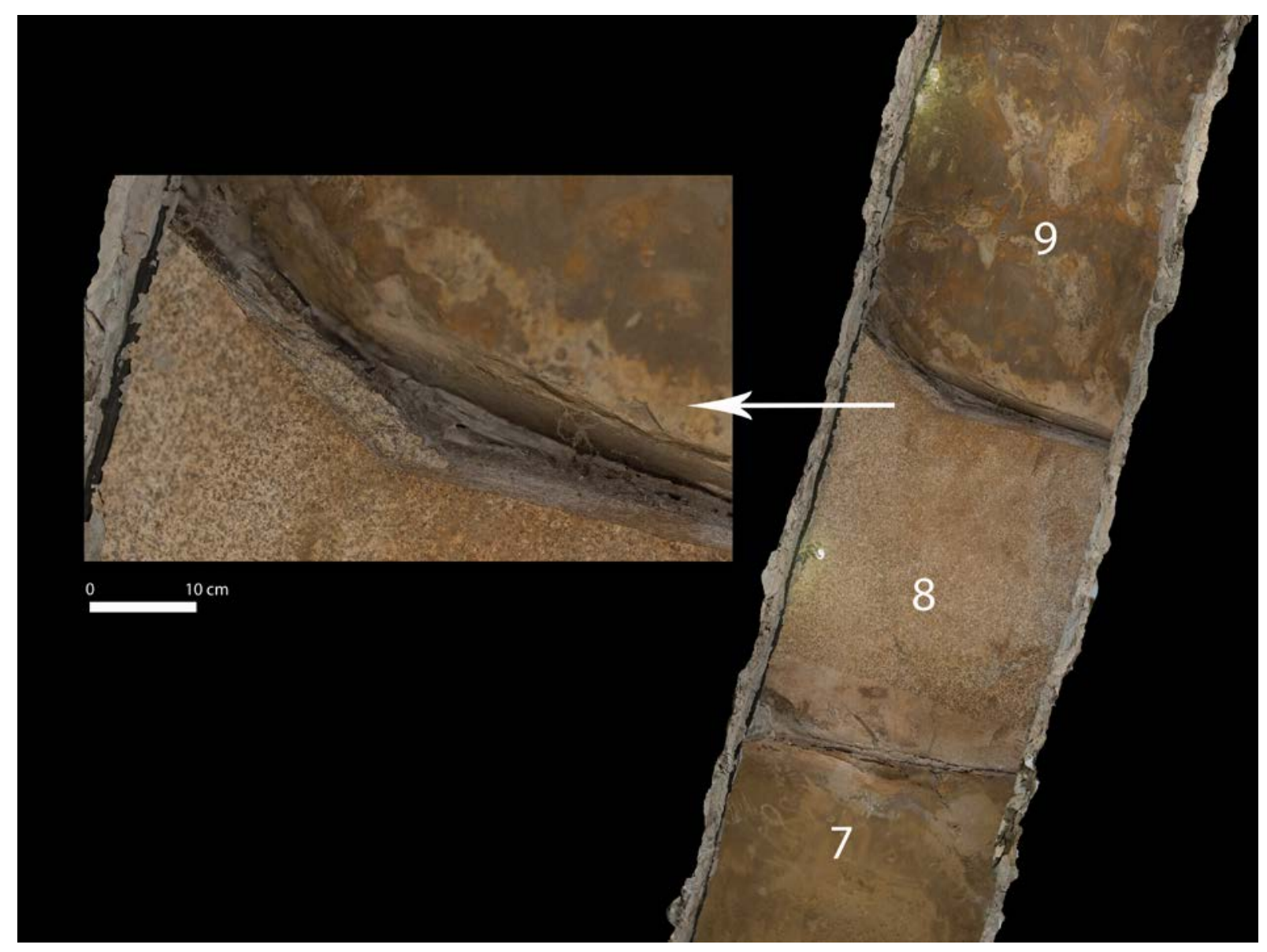

Figura 7. Detalle de corte y desbastado identificado en la losa de granito $\mathrm{n}^{\circ} 8$ de la cubierta.

a rectangulares con frentes regulares y las caras vistas uniformes, pero con irregularidades superficiales y sin indicios de desbastado, aplanado o cualquier otro tipo de tratamiento de sus caras. Los laterales se ajustan entre cada bloque denotando una selección y colocación no aleatoria. Las anchuras no son homogéneas y oscilan entre un máximo marcado por los 1,83 m del bloque $\mathrm{n}^{\circ} 7$ y el mínimo medido en el $\mathrm{n}^{\circ} 1$ con $0,60 \mathrm{~m}$; y en cuanto al espesor, se han medido valores de $0,32 \mathrm{~m}$ en las losas $\mathrm{n}^{\circ} 9$ y 11 y superiores a los $0,20 \mathrm{~m}$ en aquellos puntos donde las juntas y las roturas entre bloques han dejado el suficiente hueco.

$\mathrm{Al}$ igual que en el tramo anterior prácticamente todas las areniscas muestran elementos que en mayor o menor concentración nos remiten a una actividad bioerosiva de origen marino. Destacan especialmente las acumulaciones de varias decenas de bivalvos presentes en la superficie de las losas números 6 y 10 .

Junto a esta singularidad, señalar también otras dos detectadas en las losas $n^{\circ} 8$ y también $n^{\circ} 10$. La $n^{\circ} 8$ correspondiente al único granito de este tramo, muestra dos frentes perfilados superficialmente para formar un ángulo con la misma disposición e inclinación que el que nos muestra la losa $n^{\circ} 26$, aquella que desde el corredor se adentra con frente visible en la cámara. Es ésta una caracterización atípica que emparenta a ambas, pues además también la 26 es roca granítica. Quizás algún ensayo de corte o devastado en recto en una pieza más pequeña (la $\left.n^{\circ} 8\right)$ podría explicar esta concordancia, pues además el perfilado de la 8 es solo parcial y apreciable en unos pocos centímetros de su espesor total (fig. 7).

El caso de la $\mathrm{n}^{0} 10$ es la presencia de una amplia fractura transversal situada hacia la mitad del bloque. La separación entre las dos mitades en las que ha quedado dividido es bastante apreciable, con unos $2 \mathrm{~cm}$ de media. Hacia el interior la fractura muestra una superficie lisa que además conserva una pátina homogénea, lo que descartaría su vinculación con un episodio de rotura en época reciente. 


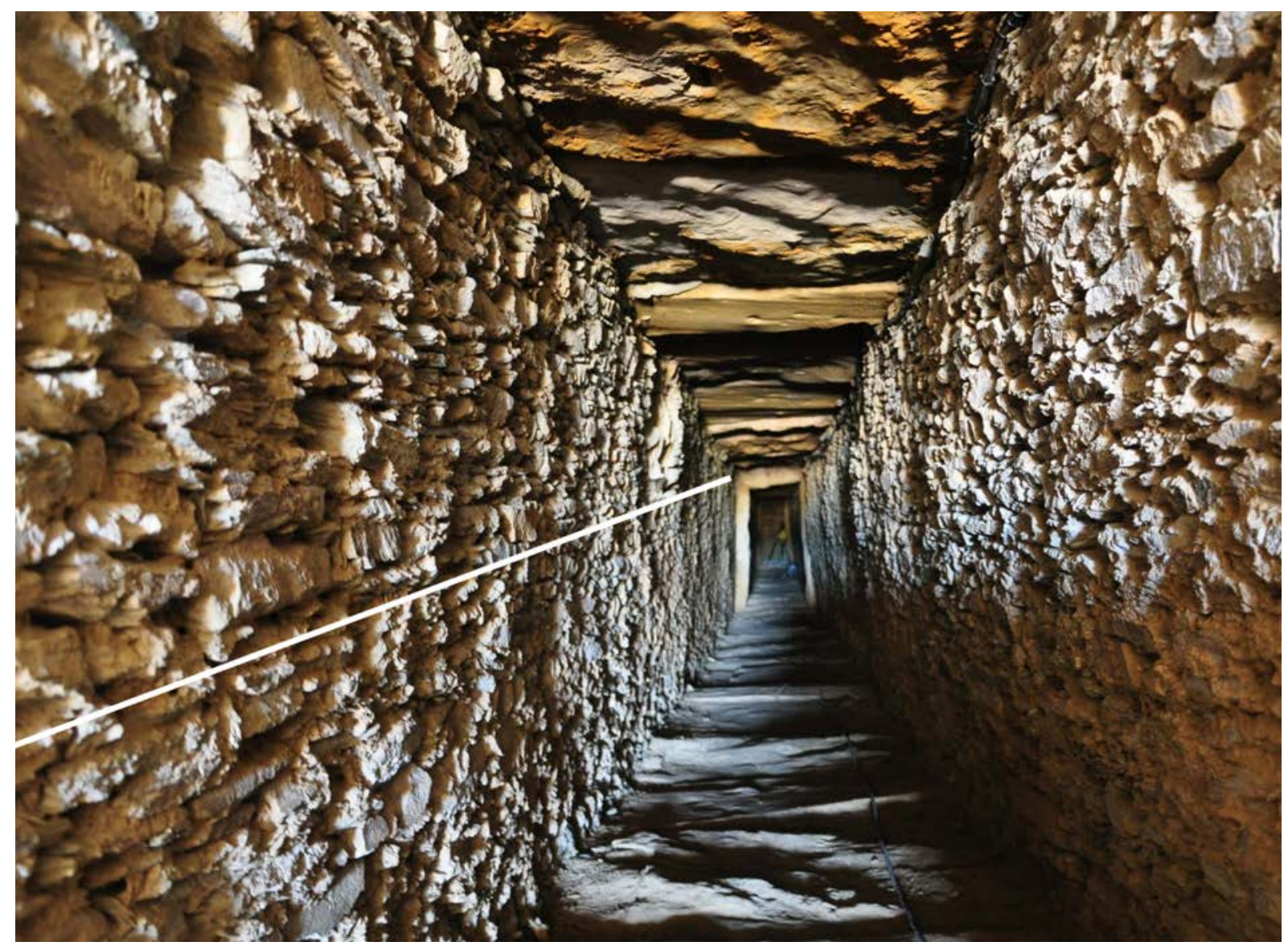

Figura 9. Interior del corredor con alineación oblicua de mampuestos dispuestos como refuerzo estructural.

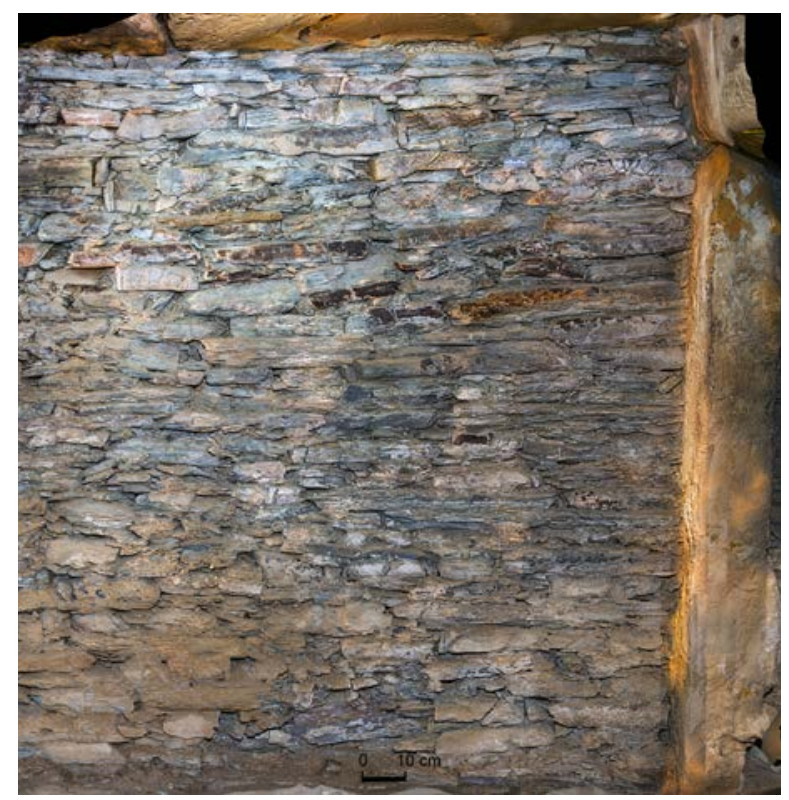

Figura 8. Detalle de la fábrica de mampuestos en el paramento norte del final del tramo intermedio del corredor.
Respecto a los paramentos, tanto el norte como el situado en el lado sur muestran una morfología similar y genéricamente equiparable a lo analizado en el tramo final. Se trata de un aparejo irregular de mampostería de bloques de cuarzoarenita exfoliados, trapezoidales y mayoritariamente alargados y dispuestos a tizón hacia el exterior y con cuñas de pequeñas lajas de nivelación que muestra la siguiente caracterización:

- Mampuestos por m²: 103 unidades.

- Forma/tamaño de mampuestos: Tamaño irregular de formas trapezoidales alargadas con una sola cara plana. Conforme a las caras visibles, existe un predominio del formato de 20-25 cm de longitud con una anchura de entre 5 y $3 \mathrm{~cm}$, con algunas piezas de mayor tamaño dispuestas a soga y que de manera aleatoria se intercalan en las hiladas mostrando medidas de entre 45 y $50 \mathrm{~cm}$ con grosores homogéneos de 6 o $7 \mathrm{~cm}$.

- Disposición de los mampuestos: Mayoritariamente se disponen a tizón hacia el exterior con las caras 
planas y regulares formando hiladas horizontales, tendentes a la horizontalidad u oblicuas con inclinación hacia la entrada. Aleatoriamente alguna pieza colocada a soga se intercala dentro de las hiladas, sin que se detecte norma estandarizada alguna.

- Máximo de hiladas: 28.

- Intersticios o juntas: Tanto las horizontales como las verticales muestran muy poca separación con mampuestos que están "a seco” unos sobre otros o con pequeños fragmentos de lajas de nivelación. En ningún caso estos intersticios van más allá de $1 \mathrm{~cm}$.

- Acabado: No se aprecia evidencia alguna de acabado exterior, salvo el plano logrado por alineación de la cara externa de los mampuestos (fig. 8).

- Conservación/patologías: Fracturas de bloques por presión superior, disgregación por exfoliado horizontal de origen natural y perdidas puntuales de algunas piezas pequeñas. También aquí las hiladas inferiores más cercanas al pavimento presentan mayor desgaste de las piezas con desaparición de las superficies planas, alteración de las juntas o pérdidas completas de algún mampuesto. En algunos sectores del paramento sur se aprecia abombamiento central de la fábrica de mampuestos.

En su conjunto los paramentos presentan una fábrica homogénea y compacta, con dos particularidades detectadas. La primera, de orden constructivo, supone la detección de una alineación de mampuestos que en todo su recorrido dibuja una línea oblicua que, desde la parte alta del muro, en su extremo este, alcanza la base de este tramo intermedio, en el extremo oeste. Se trataría de un interesante recurso constructivo de refuerzo estructural que a modo de contrafuerte utiliza el propio muro para repartir más homogéneamente las cargas generadas en la parte central del monumento, aquella donde los empujes cenitales son mayores por el impacto de las acumulaciones de tierras del túmulo (fig. 9).

$\mathrm{Y}$ en segundo lugar se trata de una interfaz detectada en la parte alta del muro sur, una rotura que parte de la cubierta del corredor hasta alcanzar la mediación del muro. En su interior se documenta una fábrica heterogénea que emplea pequeños fragmentos de lajas junto a grandes bloques calizos no desbastados ni careados, cohesionados con un mortero blanquecino que también se utiliza para el enfoscado exterior de algún sector. La parte alta se corona con un bloque de diabasa que sustituiría a aquel extraído durante la rotura, pero en este caso superponiéndose a la fábrica original. Resulta todo ello discordante de la fábrica original de mampuestos y de la ordenada cubrición de este sector (fig. 10).

El pavimento en este tramo intermedio sigue las pautas de indefinición que ya indicamos para el tramo anterior debido a los mencionados problemas de conservación. Reconocemos un total de 14 grandes losas que en algunos casos muestran oquedades circulares y también sinuosas vinculables con estructuras de origen biológico marino, así como también una curiosa colonia de ostreidos parcialmente embutida en el paramento sur y adheridos a la superficie visible de la correspondiente losa del suelo. Como en el resto del corredor hay casos de abombamiento central y de roturas transversales de losas cuyos bordes fracturados se han elevado.

\subsubsection{Tramo inicial del corredor}

El tramo inicial del corredor arranca con la compartimentación de las jambas, una con monolito conservado y otra no, que se disponen en su extremo oriental. Y finaliza en la fachada del monumento señalada por el quiebro en ángulo recto de los muros laterales que da paso a la fachada. Es el más deficiente de los ámbitos del tholos pues aquí se concentran las mayores lagunas y pérdidas constructivas tanto de los muros como de la pavimentación y la cubierta. Sin embargo, esta circunstancia nos ha permitido un estudio más detallado de la conformación interna de la construcción al liberar la coronación de los muros y su disposición interior, la superficie bajo el pavimento de losas o el corte practicado en el terreno natural.

De la cubierta nada se ha conservado, al menos en su lugar original, pues como hemos visto anteriormente las fuentes documentales analizadas ilustran la existencia de grandes monolitos desplazados por el entorno.

$\mathrm{Y}$ respecto a los paramentos, las perdidas alcanzan hasta la base del pavimento en la zona de contacto con el tramo intermedio, aquella en la que se practicaron profundas remociones y que primitivamente acogió la entrada al monumento antes del descubrimiento del tramo inicial. En el resto, las lagunas son menores y permiten definir una fábrica de mampostería con aparejo irregular de bloques de cuarzoarenita exfoliados, trapezoidales y mayoritariamente alargados dispuestos a tizón hacia el exterior y con cuñas de pequeñas lajas de nivelación que muestran una anchura de en torno a $75 \mathrm{~cm}$. En su extremo occidental los muros se estrechan (55-60 cm) y se abocinan ligeramente hacia el exterior hasta enlazar con los correspondientes a la línea de fachada. 


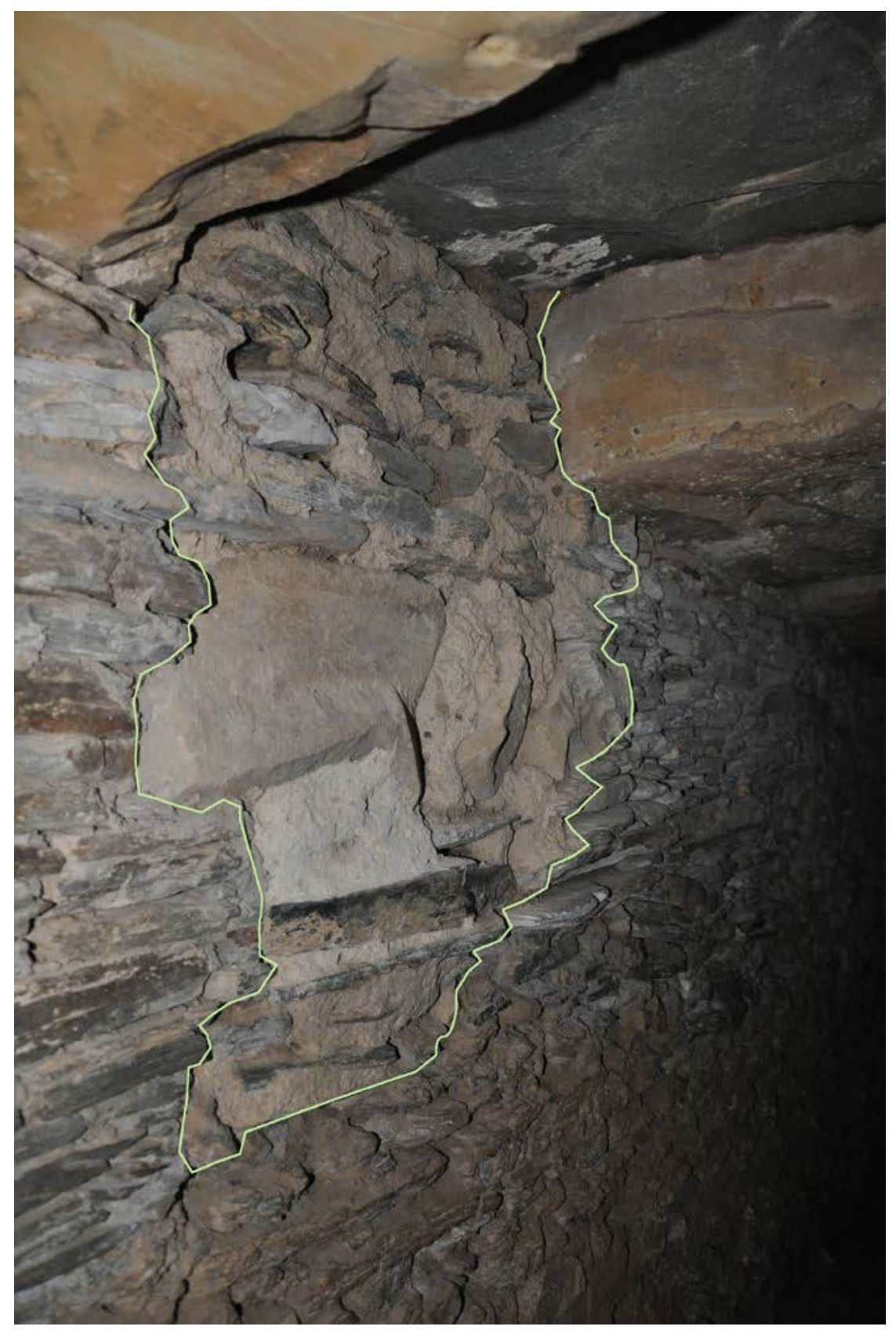

Figura 10. Interfaces de rotura correspondiente al descubrimiento y primitivo acceso al monumento.

- Mampuestos por $\mathrm{m}^{2}: 99$ unidades.

- Forma/tamaño de mampuestos: Tamaño irregular de formas trapezoidales alargadas con una sola cara plana. Se pueden aislar dos tipos en función del grosor: los de medida igual o superior a $5 \mathrm{~cm}$ y los que están por debajo de los $5 \mathrm{~cm}$ que mayoritariamente tienen espesores de 2-3 cm. Las longitudes de las caras visibles son variables, siempre por debajo de los $40 \mathrm{~cm}$ en los ejemplares más grandes, y con una media general de $15-20 \mathrm{~cm}$. En las tres/cuatro filas inferiores se disponen los mampuestos de mayor tamaño.

- Disposición de los mampuestos: En hiladas horizontales o tendentes a la horizontalidad, a tizón hacia el exterior con las caras planas y regulares (careadas) y trabazón interior de los mampuestos. No se trata de un relleno interno heterogéneo y descuidado, sino de una fábrica ordenada de no 
Figura 11. Detalle de la estructura interna de los muros de mampuestos entre el sustrato natural excavado (arriba) y las losas del suelo (abajo).

Lado norte del tramo inicial del corredor.

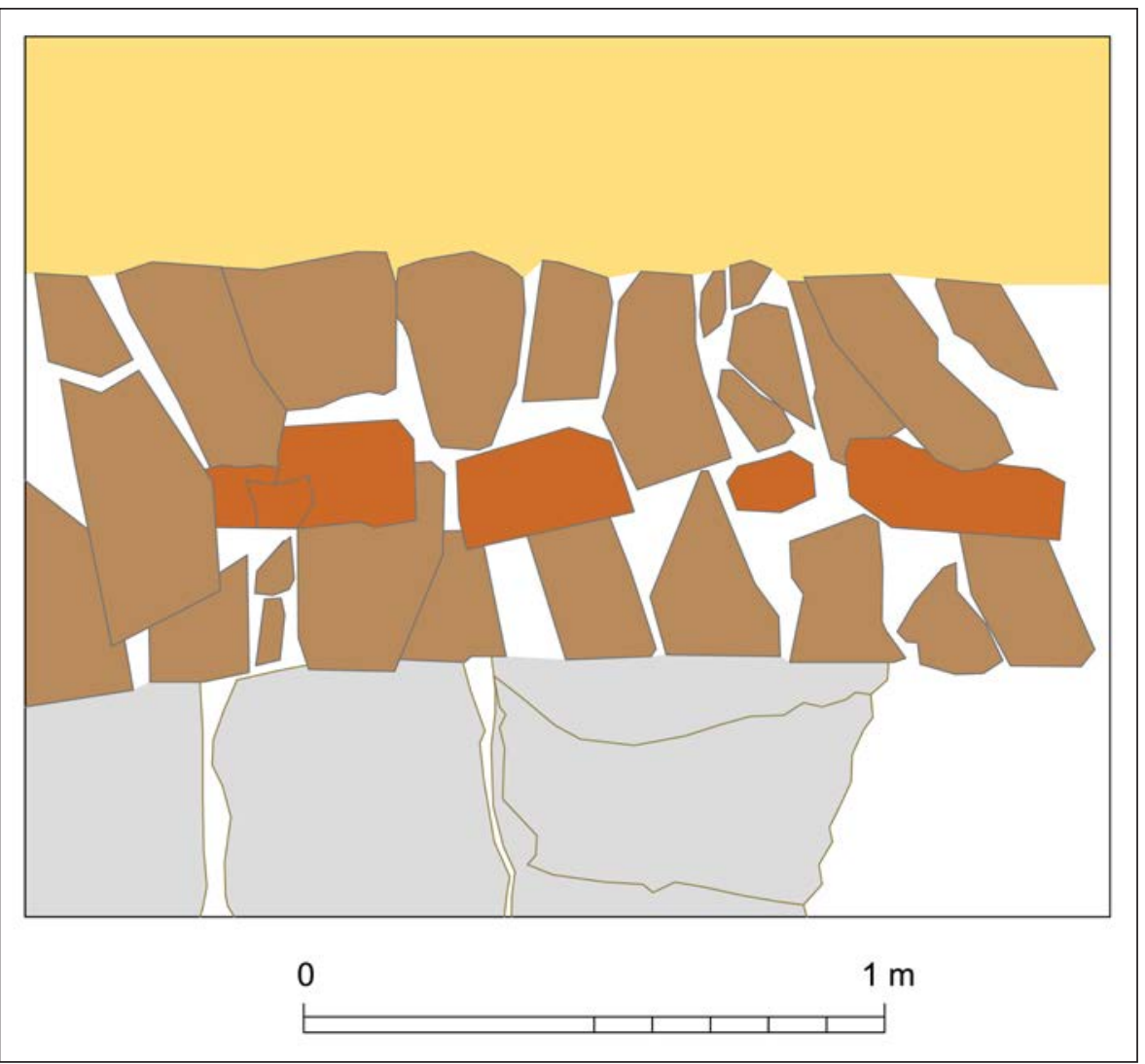

más de tres alineaciones por hilada; dos forman las caras externas del muro y la tercera interna, traba las anteriores mediante mampuestos a soga (fig. 11).

- Máximo de hiladas (conservadas): 14.

- Intersticios o juntas: Las horizontales entre hiladas (tendeles) muestran una media de separación de entre 2-3 cm. Las juntas verticales se sitúan de forma salteada entre hiladas y muestran una media de separación entre los mampuestos de 1-2 cm. Se detectan pequeños fragmentos de lajas calzando los mampuestos y relleno de tonalidad marronácea y textura arcillosa que enrasa hasta la cara vista sin que, por tanto, conste llagueado alguno.

- Acabado: No conserva tratamiento alguno en las superficies de los muros.

- Conservación/patologías: Disgregación constructiva en la hilada más superficial con pérdida del relleno de los intersticios y desplazamiento de los mampuestos. En el tercio más oriental se ha perdido la práctica totalidad de las hiladas hasta la cota de pavimento, únicamente con pervivencia de algún mampuesto aislado.
El pavimento en este tramo presenta también importantes pérdidas. Como en el resto del monumento, estuvo conformado por grandes losas de piedra de las que se han conservado un total de 12 unidades. En el extremo oriental y aislada, siempre ha llamado la atención la losa de cazoletas, así denominada por la profusión de oquedades circulares apreciables en su cara visible. De su análisis estratigráfico deducimos que es pieza desplazada; varias razones apuntan a ello: en la limpieza de sus bordes se aprecia cómo no se embute en el subsuelo, más bien apoya, y tampoco aparece enmarcada por mampuesto alguno; su cota superior se encuentra por encima de la línea de pavimento original y también respecto de la losa más cercana $(3 \mathrm{~cm})$ e igualmente esta mayor altitud inhabilita que los muros laterales se superpongan cubriéndola por sus bordes, que es el esquema constructivo general. Además, no conecta con ninguna otra losa del suelo, ni hacia el interior del corredor ni hacia el occidente donde curiosamente se extiende un amplio vacío. En realidad, se muestra orientada y respetando el lugar que ocupaba el sardinel que se realizó para colocar la primera verja de cierre. Digamos que constructivamente está “suspendida” en un 
espacio que nos consta bastante alterado y sin conexión alguna que permita relacionarla de forma directa con la fábrica original del monumento. Por ello, es probable que se colocara en ese espacio previo exterior para el acondicionamiento de la entrada reaprovechando alguna de las losas de la cubierta del monumento que se encontraban removidas de su lugar original.

Al otro lado, en el inicio del corredor, la primera losa del pavimento es también elemento reutilizado pues se trata de un bloque que hemos podido identificar en antiguas imágenes que lo sitúan en diferentes lugares. En primer lugar, en su emplazamiento primitivo como jamba lateral al inicio del corredor (Ruiz 2013: 212, fig. 8), después en su desplazamiento hacia el exterior, fuera de la construcción (Gómez de Terreros 2005: 135 , figs. 70,71 y 72 ) y finalmente en el interior del pasillo sobrepuesta a los rellenos excavados en 1991-92 (Vargas 2004: 100, lám. 23).

A partir de este último punto y hasta la fachada no existe ningún bloque más por lo que parece que fue un espacio que nunca tuvo pavimento con losas (Ruiz y Martin 1993: 555). Ello, unido a la presencia del muro interior de taponamiento del tholos y su coincidencia con el ámbito en el que los muros laterales se estrechan y abren hacia el exterior, le confieren un carácter singular y claramente diferenciado respecto de la situación general de la construcción, y en particular de este tramo inicial.

\subsubsection{Fachada}

En este ámbito distinguimos por un lado la fachada propiamente dicha, es decir la obra de terminación exterior de la construcción, y por otro la estructura de taponamiento que en parte oculta el frente de fachada y se adentra en el corredor.

La primera supone la continuación, en quiebro, de los muros laterales del inicio del corredor con similar morfología y dimensionado. Se trata de un aparejo de mampuestos que conforman un muro de una anchura no superior a los $60 \mathrm{~cm}$. Se trata de cuarzoarenitas exfoliadas, trapezoidales, mayoritariamente alargadas dispuestas a tizón hacia el exterior y con cuñas de pequeñas lajas de nivelación. Las hiladas son horizontales o tendentes a la horizontalidad con trabazón interior de los mampuestos y hacia el exterior, las caras planas y regulares, las caras internas aparecen desdibujadas y sin un frente regular. Se singulariza por conservar un acabado exterior que muestra un aplacado de losas verticales de cuarzoarenitas (fig. 12).
Respecto del taponamiento contamos con una parte todavía conservada junto a la fachada, así como con las imágenes conservadas en el archivo personal de Collantes y también con la descripción de su excavación y retirada en el inicio del corredor (Ruiz 2013: 212). De modo que podemos decir que se trataba de una estructura de mampuestos de cuarzoarenita con alternancia de hiladas a soga y a tizón y un frente rectilíneo en su límite oriental, en el interior del corredor. Hacia el exterior se despliega unos 2,5 metros a ambos lados de la entrada y se adosa, ocultando, al frente de fachada; por esta parte el límite exterior es impreciso sin frente alguno.

\section{DISCUSIÓN}

A partir de este análisis de la construcción del tholos de La Pastora se pueden plantear algunas cuestiones de interés.

Según las fuentes, podemos reconstruir cómo en el momento del descubrimiento de La Pastora el relleno interior de la cámara y del corredor era de unos escasos $10 \mathrm{~cm}$ y ello además se puede confirmar por las huellas perceptibles en los tramos inferiores de los muros (fig. 8). Era pues un lugar vacío, donde las filtraciones del terreno habían formado esa pequeña capa depositada sobre el pavimento, si bien su función como lugar de enterramiento quedaba probada al localizarse restos humanos, hoy perdidos, en la cámara y zona próxima del corredor. Otros materiales arqueológicos singulares ilustran la notoriedad de los ajuares que en algún momento pudo llegar a albergar, puesto que con el tholos de La Pastora se relaciona no solo el conjunto de jabalinas sino también otras piezas de malaquita, concha, cobre y oro, que en su momento fueron donadas al MAN, aunque no todas se conserven (Almagro 1962: 7 y 20 , fig. 6).

Los sectores del túmulo que fueron alterados en aquellas fechas fueron tres: en primer lugar, y es obvio, la zona del corredor por donde se descubrió y accedió inicialmente, pero también y a su alrededor, un irregular espacio que ha quedado claramente marcado por las anomalías de la prospección geomagnética realizada (Vargas et al. 2012: 127, fig. 6). En este lugar se midió una potencia de entre 1 y $2 \mathrm{~m}$ de tierra acumulada. Más hacia el oeste, pero en las proximidades, otra zona alterada es aquella que se practicó con objeto de localizar la primitiva entrada, dando lugar a importantes remociones que, según hemos podido verificar, alcanzaron hasta la propia cota de pavimento del tholos. Estas alteraciones afectaron también al tramo inicial del monumento 


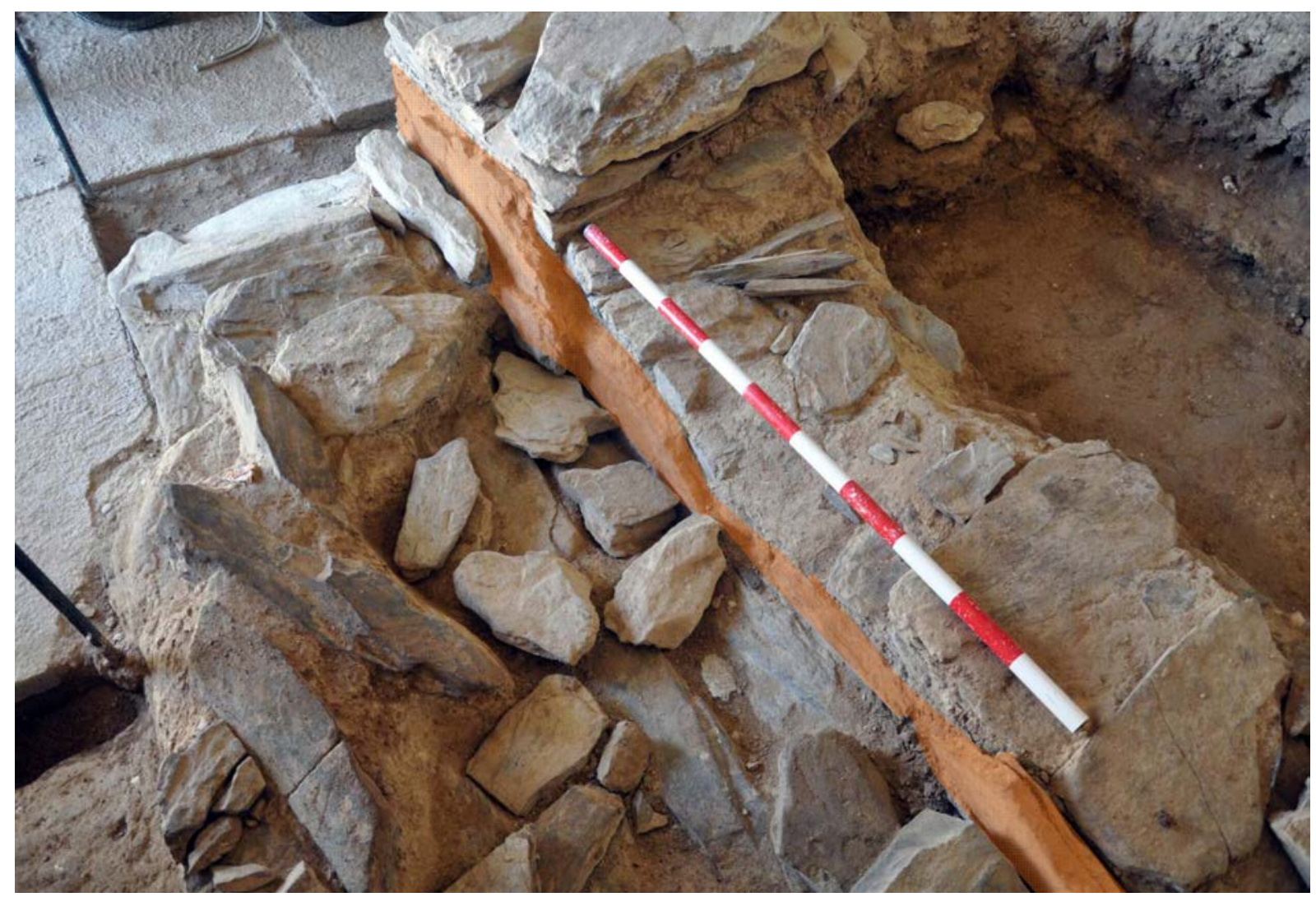

Figura 12. Fachada sur con indicación de línea de aplacado vertical conservada y estructura de taponamiento que la oculta.

que presentaba un comportamiento estratigráfico diferenciado, al mostrarse, en este caso, totalmente colmatado. En la más antigua imagen conservada (Obermaier 1919: 31, fig. 11) se aprecia claramente la entidad de este socavón. Y finalmente, también en la parte del túmulo que cubre la cámara se realizaron remociones que permitieron a Tubino indicar la existencia de unos dos metros de acumulación de tierras.

De la cámara, en atención a los datos de estas fuentes, podemos resaltar dos aspectos. El primero es que la altura máxima a la que aluden los textos no concuerda con las medidas actuales, siendo además significativo que tanto Tubino como Cañal al describirla aluden claramente a que el suelo se encontraba más bajo que en el corredor, cuando en la actualidad está justamente al contrario, algunos centímetros más alto en la cámara.

El segundo lo es por omisión, pues nada se dice sobre la hornacina que hoy adorna su interior, ni siquiera por Obermaier, como erróneamente ha sido planteado por Ruiz (2013: 207). Lo cierto es que nadie había reparado en ello.
No creemos que pudiera pasar desapercibido para Tubino o Cañal que, en sus minuciosos relatos, nada señalan sobre su existencia, cuando por ejemplo en el caso de su descubridor se detiene en detalles tan particulares como la presencia de pequeñas conchas marinas en el suelo o entre los bloques superiores de la propia cámara, y nada cita de la existencia de la supuesta hornacina (Tubino 1868, Cañal 1894). El análisis estratigráfico apunta a elementos que difieren claramente de la uniformidad estructural del resto de la cámara, pues para formar el hueco de la llamada hornacina fue necesario realizar: el giro del bloque del fondo, ocultando la zona de tono rojizo que en el resto aparece como cara vista (fig. 13-1); con ello el bloque superior quedó descalzado por uno de sus lados y con una visible línea de separación entre el tono rojizo de la zona dispuesta para verse y aquella parte que originalmente estuvo oculta (tono gris), ello señala el lugar que debió ocupar el bloque original extraído (fig. 13-2); los laterales y la base se recubrieron con un aparejo diferente con recortes de lajas y mampuestos en vertical, en una disposición que únicamente se constata en este lugar 


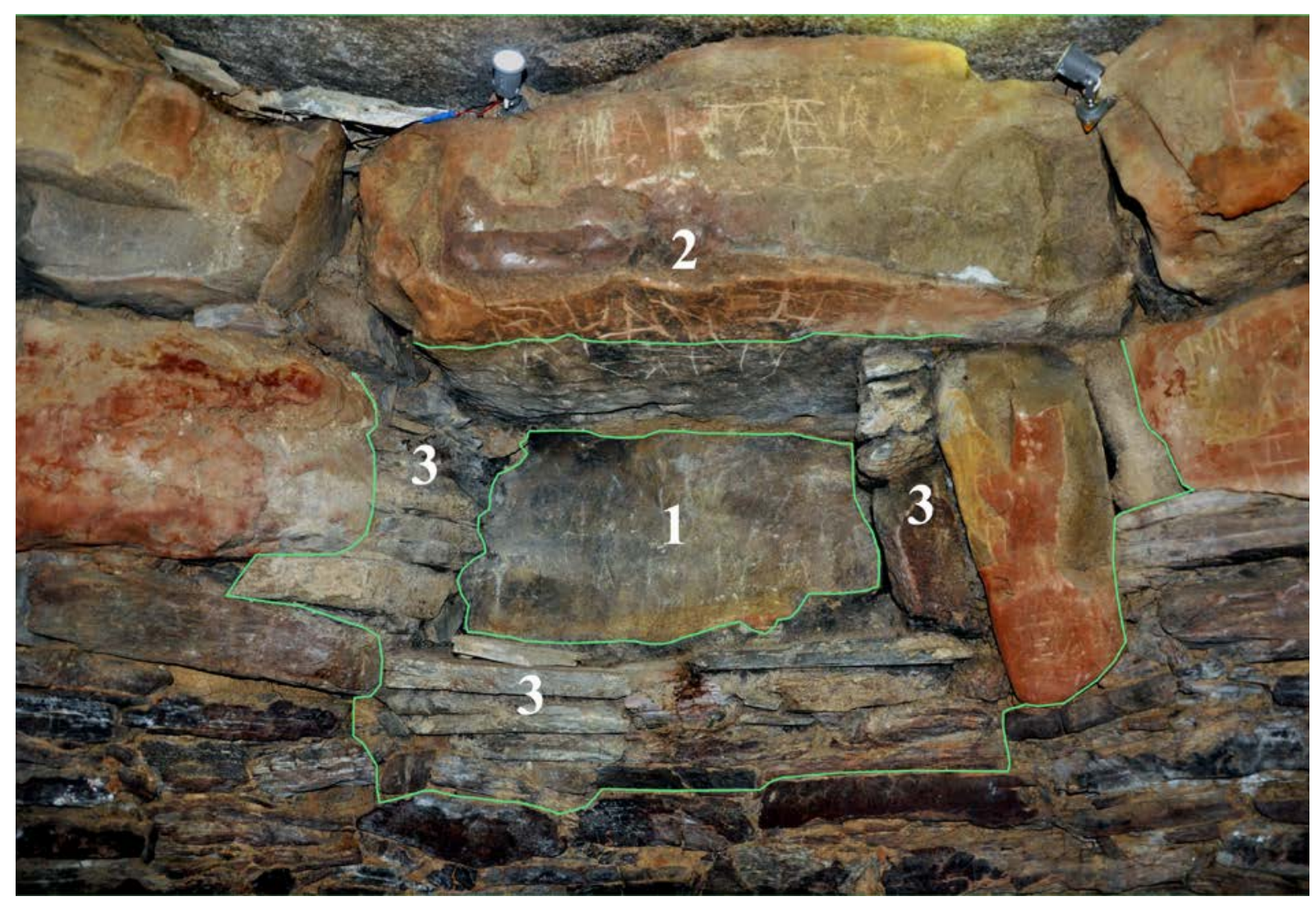

Figura 13. Hornacina de la cámara con indicación de elementos registrados durante el análisis constructivo.

(fig. 13-3); y finalmente la interfaz estratigráfica se señala además por la presencia como material aglutinante de todo este conjunto, de un mortero muy compacto de tono gris oscuro, en todo diferente de las arcillas depuradas marronáceas que hemos podido reconocer entre los intersticios de los mampuestos de la fábrica original (Vargas et al. 2019). Nos parece claro que con posterioridad a 1919 (Obermaier 1919: 33) se produjo esta intervención, probablemente con la intención de colocar alguna imagen que cristianizara el lugar, en un fenómeno que ha sido reconocido en diferentes lugares y es especialmente profuso en el Alentejo portugués (García Sanjuán 2008: 42).

En la cámara y por debajo de estos elementos se dispone la fábrica de mampuestos de cuarzoarenita, que en gran parte muestra una singular coloración rojizo-parduzca de origen natural, como consecuencia de procesos de oxidación a lo largo de fracturas y discontinuidades coincidentes con alguno de sus frentes. Probablemente, hubo un proceso de selección en el que se buscaran los bloques más teñidos, quedando más remarcado este aspecto en la cámara del monumento, pues en ningún otro lugar se presenta dicha concentración.

En esta línea indicamos cómo el tramo de cierre de las areniscas también se subraya mostrando su frente visto con una acusada coloración rojiza. En este caso estamos estudiando su posible origen, natural o antrópico, pues dicha coloración no es generalizada en toda la roca ni parece que obedezca a algún material del que se haya impregnado por contacto o pueda estar causada por la aspersión de algún pigmento.

En consecuencia, los constructores podrían haber buscado un efecto de tamizado rojizo superficial en toda la cámara que aún hoy y especialmente en condiciones de alta humedad puede observarse, lográndose además un mayor grado de perdurabilidad frente al uso de pigmentos empleado en otros megalitos (fig. 14).

En el corredor, y en los tres tramos en los que está divido, la fábrica de los muros es bastante homogénea con presencia de un aparejo irregular de mampuestos de cuarzoarenita exfoliados, trapezoidales y mayoritariamente alargados dispuestas a tizón hacia el exterior 
Figura 14. Tonos rojizos apreciables en la superficie exterior de los muros de la

cámara.

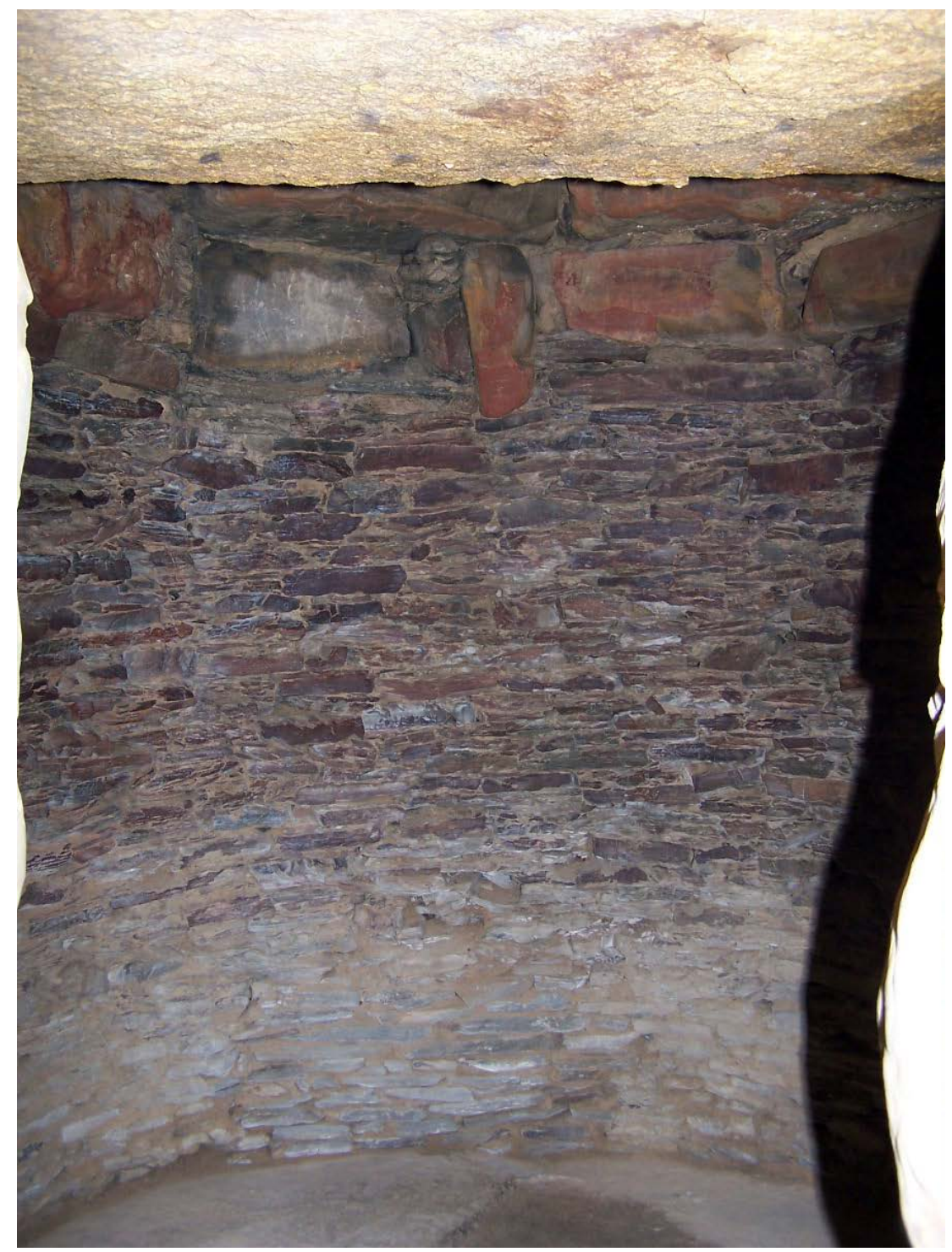

y con trabazón interna de piezas dispuestas a soga (fig. 11). Se muestran en hiladas horizontales o tendentes a la horizontalidad, con cuñas de pequeñas lajas de nivelación. El número de mampuestos por $\mathrm{m}^{2}$ es prácticamente coincidente (105 en el final, 103 en el intermedio y 99 en el inicial) y el módulo de pieza mayormente utilizada también, pues recurrentemente son piezas con una longitud visible de entre 15 y $25 \mathrm{~cm}$ y un espesor de entre 2 y $6 \mathrm{~cm}$. También es común la colocación aleatoria u ordenada, en algún tramo de hiladas, de piezas de mayor tamaño y espesor (40-50 cm y 5-8 cm). Las juntas entre hiladas y/o mampuestos son inexistentes ("a seco") o de 1-2 cm, y no podemos considerar que el relleno interior, marrónaceo, depurado y muy fino, documentado en sectores con pérdidas, pueda corresponder a algún tipo de mortero. Es por todo ello un tipo de construcción que se repite para todos los muros y que con las debidas reservas históricas puede asimilarse al tipo 6 de la clasificación clásica de aparejos murarios (Parenti 1988: 292, fig. 3).

Dentro de esta homogeneidad podemos señalar algunas singularidades. Constructivamente y muy posiblemente también con connotaciones simbólicas, la colocación de los monolitos correspondientes a las llamadas puertas que compartimentan el monumento son un hito principal del proceso de edificación, pues hemos constatado estratigráficamente su posición en el inicio de la secuencia constructiva. Poseen un significativo 
valor estructural y de diseño, pues serían verdaderos elementos-guías de la construcción, a modo de pilares maestros que siguiendo un plan preconcebido se colocan al inicio de los trabajos para servir de referencia física en la alineación de los muros y la nivelación de las losas de cubrición. Ello acentúa el valor del monumento como estructura planificada y convenientemente dirigida durante su construcción (fig. 3).

Conforme a esto, nuestra propuesta de reconstrucción edilicia parte de una orientación específicamente calculada, atendiendo probablemente a criterios astronómicos (Belmonte y Hoskins 2002: 98) que permite delimitar y excavar una amplia zanja. Conforme a las medidas que hemos podido detectar, dicha zanja vendría a tener una anchura de unos 2,50 m y una longitud estimada en unos $48 \mathrm{~m}$. Tras el vaciado de esta zanja se colocarían los monolitos verticales correspondientes a la compartimentación del megalito como elementos-guía de la construcción que hemos definido. Seguidamente se alinean y colocan las diferentes losas del pavimento que en algún punto pudieron estar parcialmente embutidas en la base de la zanja (Ruiz 2013: 213). A continuación, se prosigue con la realización de los muros de mampostería que hemos documentado como apoyan sobre el pavimento, pero solo parcialmente pues en su desarrollo en anchura y profundidad superan a las losas del suelo envolviéndolas por el extremo de sus lados cortos. En las zonas mejor conservadas es evidente como los muros apoyan sobre el pavimento, pero también en el tramo inicial, mas destruido, se han podido reconocer hiladas de mampuestos por debajo de la cota de pavimento y más allá de sus límites. De igual modo ocurre con los monolitos de las puertas que son rodeados por estos muros dándoles cobijo y sustentación. La colocación de las hiladas de mampuestos se desarrolla a la inversa de nuestra lógica constructiva, pues se parte de un plano inclinado hasta alcanzar un plano horizontal que es el que ha quedado definido por la coronación superior de los dinteles de los monolitos de compartimentación. A partir de ese plano son colocadas las losas de la cubierta siguiendo un orden que culmina con la de la cámara que es donde se coloca la última losa. En este punto hemos de decir que el corte natural del terreno ha quedado por debajo de la cota de coronación de los muros, por lo que en ningún caso el terreno natural cortado se utiliza para el sostenimiento de la cubierta. Claramente son los muros laterales quienes soportan todos los empujes superiores tanto de las losas de la cubierta como de la potente acumulación de tierras del túmulo.
Ello explicaría algunas de las singularidades estructurales que hemos podido detectar en el análisis estratigráfico. Es el caso localizado en el tramo intermedio, donde se ha documentado la existencia de un plano inclinado en la construcción de los muros laterales, más claramente apreciable en el lado norte que en el sur. Se trata de un ángulo agudo con vértice en la zona superior del dintel de la puerta intermedia y apertura hacia la zona inferior del tramo inicial. Las hiladas de mampuestos se disponen siguiendo esta inclinación (fig. 9).

Pero también en esta línea situaríamos las alineaciones de refuerzo con hiladas a soga de mampuestos de mayor tamaño del tramo inicial, la propia erección de los monolitos de compartimentación (puertas) como pilares maestros de la edificación y también el conjunto de estructuras de la geomagnética realizada en el túmulo (Vargas et al. 2012: 135, fig. 8), pues la localización de posibles muros circulares y radiales crean un entramado interior sin duda necesario para la sustentación de la acumulación de tierras que contenía. Es por tanto necesario resaltar que, con independencia de las razones simbólicas que no descartamos, existen también argumentos de naturaleza técnica estructural que explican la aplicación de determinadas soluciones de diseño y praxis constructiva para la erección de tan potente construcción y ello además no desde la casualidad o la improvisación, sino fruto de una experiencia previa materializada de forma precisa durante la ejecución de la obra.

En todo el corredor la única interfaz detectada se ha documentado en la pared norte del tramo intermedio y hemos visto como se trata de una rotura producida desde la cubierta que alcanza a la fábrica original del muro originando un taponamiento posterior con un aparejo descuidado con presencia de bloques calizos no devastados y un mortero de cal y arena. La losa de la cubierta es sustituida por una diabasa que además no encaja en la posición original, sino que se sobrepone apoyando en las losas colindantes, y finalmente en el exterior coincide con una concentración de anomalías detectadas por la geomagnética que indican alteraciones del terreno. Todo ello, señales inequívocas de que se trata de un elemento asociado a un evento posterior al de la construcción original y que relacionamos con el lugar de descubrimiento y primitivo acceso al tholos, pues además su localización no es discordante con el dibujo original de su descubridor. La clausura de este acceso y por tanto de la obra de reparación se debió producir en una fecha anterior al relato de Cañal (1894) que ya recoge el cierre de esta primitiva entrada (Vargas et al. 2019) (fig. 10).

En el tramo inicial del corredor la deficiente conservación y la complejidad de la documentación existente 
sobre las antiguas excavaciones han supuesto un reto de análisis e interpretación arqueológica y constructiva.

Efectivamente, el tramo inicial del corredor puesto al descubierto durante las excavaciones de 1963 se encontraba notablemente alterado. Las imágenes conservadas lo muestran con una total ausencia de losas de cubrición y presencia de un relleno interior que colmataba todo su recorrido (fig. 15). Los materiales nunca llegaron a publicarse, pero dos referencias de la, por entonces, directora del Museo Arqueológico de Sevilla son claras al vincularlos con época prehistórica (Fernández Chicarro 1964: 101 y Fernández Chicarro 1974). No se trata de contextos in situ sino de rellenos que contienen material prehistórico, lo que sugiere que esta situación se produjo al poco tiempo de abandonarse. Las circunstancias precisas no podemos conocerlas, si bien el desmantelamiento de toda esta parte, en la propia época prehistórica pudo ser un evento de clausura definitiva, acaso como reacción a la profanación y el expolio de los ajuares que poco tiempo después de su deposición se acometió a través de aquella parte más sensible y accesible del túmulo, esto es la más próxima a la entrada, en la que además menor cantidad de tierra habría que retirar.

Por ello, frente a la posibilidad -como ocurre en otras construcciones megalíticas tipo tholos-, de que este tramo inicial nunca llegara a estar cubierto, nos inclinamos por plantear lo contrario $\mathrm{y}$, como veremos más adelante, tan solo el tramo final, de un par de metros, creemos que pudo permanecer descubierto. Al respecto indicamos cómo estructuralmente los muros laterales siguen la tónica general del monumento y debido a su dimensión, capacidad de carga y potente implantación no se entenderían salvo como sustento de la cubierta. De igual modo, en el tramo de muro mejor conservado (mitad del lado norte) la cota máxima es trasladable y coincidente con la alineación de toda la cubierta del monumento que, recordemos, es calculadamente horizontal frente a la inclinación del suelo. Y finalmente, la presencia de las propias losas o más bien fragmentos de ellas se puede rastrear en las fuentes antiguas, que la mencionan en relación con las jabalinas, pero también en los trabajos de 1963 y no solo porque son reconocibles en las antiguas fotos, sino porque además fueron objeto de una experiencia de traslado manual (Gómez de Terreros 2005: 135). Son a nuestro parecer argumentos difícilmente entendibles desde la perspectiva edilicia, si no es por la continuación hasta esta parte de la cubierta del corredor. La posibilidad apuntada para otros lugares de que pudieran existir demoliciones deliberadas con fines de clausura definitiva

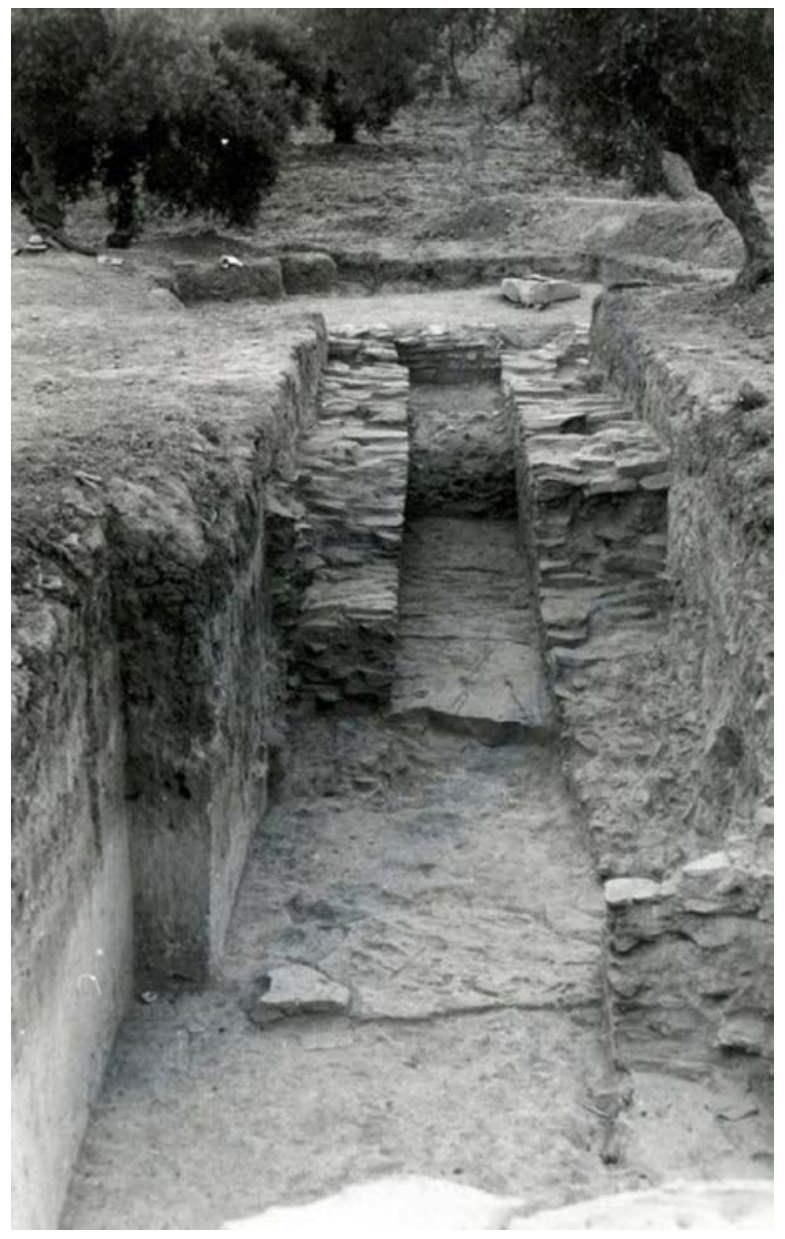

Figura 15. Vista hacia el oeste del tramo inicial del corredor durante la excavación de su colmatación interior; al fondo, gran losa removida. Imagen de 1963 procedente del Fondo Collantes, caja n ${ }^{\circ}$, Dpto. de Prehistoria y Arqueología de la Universidad de Sevilla.

(Delibes 2004: 219) pudo provocar la fragmentación y pérdida de las losas, así como la presencia de materiales exclusivamente prehistóricos en el correspondiente relleno.

Hemos visto cómo no existen diferencias reseñables respecto al módulo de aparejo conservado en todos los muros del corredor. Tampoco en este tramo inicial donde la pérdida de la cubierta o la interrupción de los muros laterales por destrucción ha creado un falso efecto fachada, realzado por el rehecho de su frente de corte al alinearlo con la construcción de la casamata de hormigón, lo que genera aún más confusión constructiva. A nivel arqueológico y recurriendo al tramo inferior, se aprecia claramente la continuación de los muros laterales, rodeando a las jambas de la puerta, sin que se 


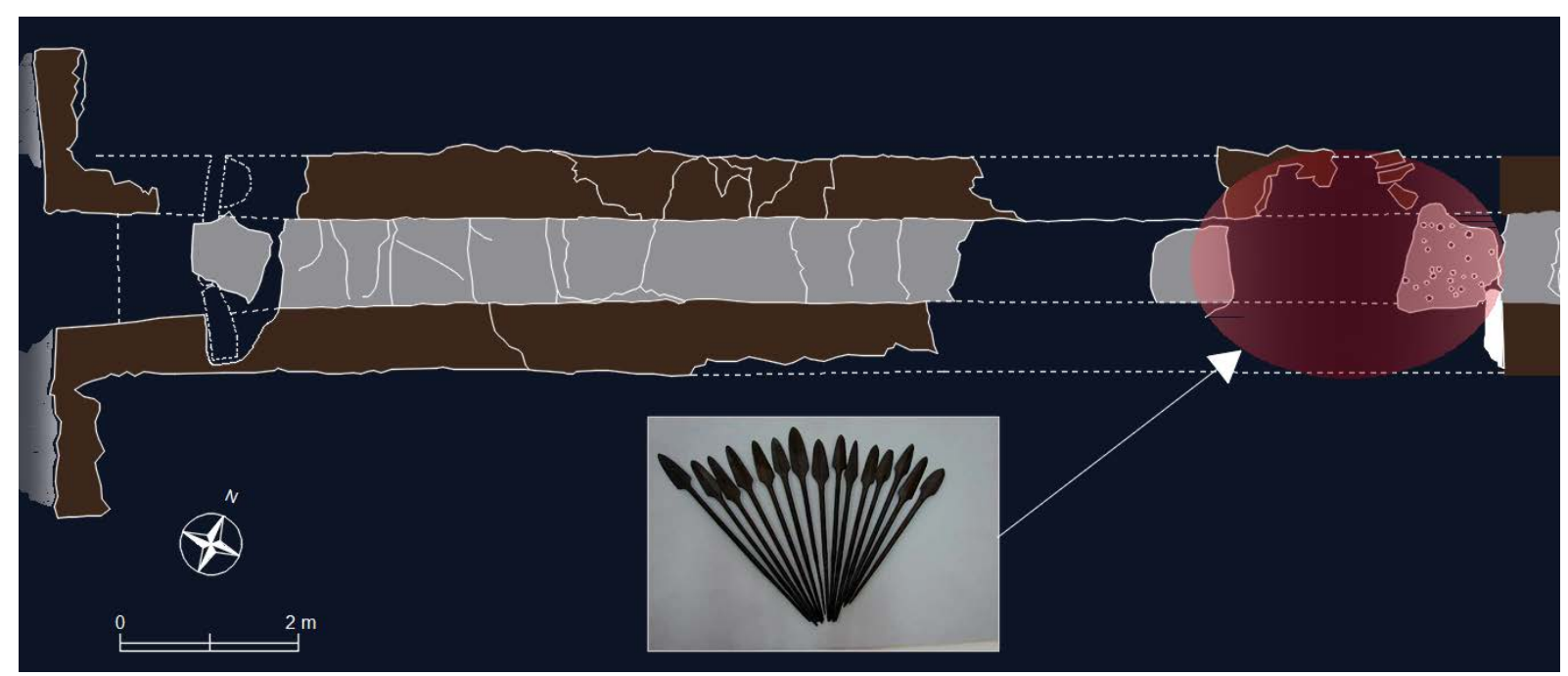

Figura 16. Tramo inicial del corredor. Se indica el probable lugar de localización de las jabalinas.

haya verificado interrupción alguna de los muros que vienen del tramo intermedio.

No existe por tanto diferenciación alguna que sustente la existencia de una tipología de construcción diferente o realizada en una fase distinta.

En esta zona de contacto del tramo inicial de corredor con el intermedio, una gran interfaz de destrucciones es la responsable de la situación de arrasamiento de los muros hasta las cotas más profundas. Tan solo unos pocos mampuestos en ambos lados marcan su línea de continuación. Es este el sector más fuertemente alterado de todo el tholos, con mayores remociones que muy poco han dejado de la estructura original, y se corresponde, además, con la profunda depresión topográfica observable en las primeras representaciones de la primitiva entrada (Candau 1894: 34, Cañal 1894: 191, Obermaier 1919: 31). La coincidencia del lugar con las antiguas descripciones sobre la aparición de las jabalinas, "no lejos de la entrada artificial del subterráneo" (Tubino 1868), “a la entrada misma de la galería” (Gestoso, 1889), permiten señalarlo como el lugar exacto de donde fueron extraídas dichas piezas. Ello, sin duda, fue a la vez causa y efecto de la situación de alteración sedimentaria y de la perdida de componentes edilicios que hemos señalado (fig. 16).

Al hilo de lo anterior, las jabalinas aparecieron en el interior de un recipiente y bajo una gran piedra (Tubino 1868), lo que en esta localización significaría específicamente bajo alguna losa de cubrición del corredor. De modo que, o bien se desplazó en un momento posterior para su ocultamiento, en línea con la propuesta que lo asocia a una reutilización del espacio (Montero y Teneishvili 1996: 74) que a su vez se interpreta como ofrenda sobre el túmulo (García Sanjuán 2005: 91); o por el contrario pertenece a un deposito antiguo realizado en el interior del propio monumento. La interfaz estratigráfica contemporánea que permitió su descubrimiento podemos afirmar que alcanzó hasta la propia cota de pavimento, por lo que la ubicación de las jabalinas entre los niveles más antiguos no es descartable. Y por tanto, tampoco lo es que pertenecieran al uso funerario inicial de la construcción.

En el otro extremo del tramo inicial y próximo a la fachada (a 2 m) aún hoy se conservan dos pequeñas zanjas transversales abiertas sobre el subsuelo que fueron sacadas a la luz durante los trabajos de 1991/92 (Ruiz 2013: 212). Con algo más de $20 \mathrm{~cm}$ de anchura, parten del interior de cada uno de los muros laterales llegando a conectar la una con la otra, de modo que ocupan toda la anchura del corredor (fig. 16). La del sur daba cobijo a un gran ortostato vertical de cierre del pasillo que fue retirado durante los trabajos de 1963, y también este mismo destino parece que pudo tener la otra zanja, en este caso con el ortostato desaparecido. Ello derivaría en la existencia de un auténtico cierre del monumento, no en fachada sino un poco más hacia el interior y teniendo su trabazón interna con los muros laterales, lo cual significaría que fue diseñado para su colocación durante la fase final de la construcción del monumento y no como un elemento removible tipo "puerta” que se superpone y/o apoya, posibilitando sucesivas aperturas y cierres. El caso es que al estar encastrado en la propia obra de los muros, su retirada implicaría forzosamente una amplia rotura de la fábrica de mampuestos laterales, y esta 
Figura 17. Restitución de la fachada y del tramo inicial del corredor tras la clausura del monumento: A. Losa de cierre,

B. Estructura de taponamiento y C. Aplacado de fachada.

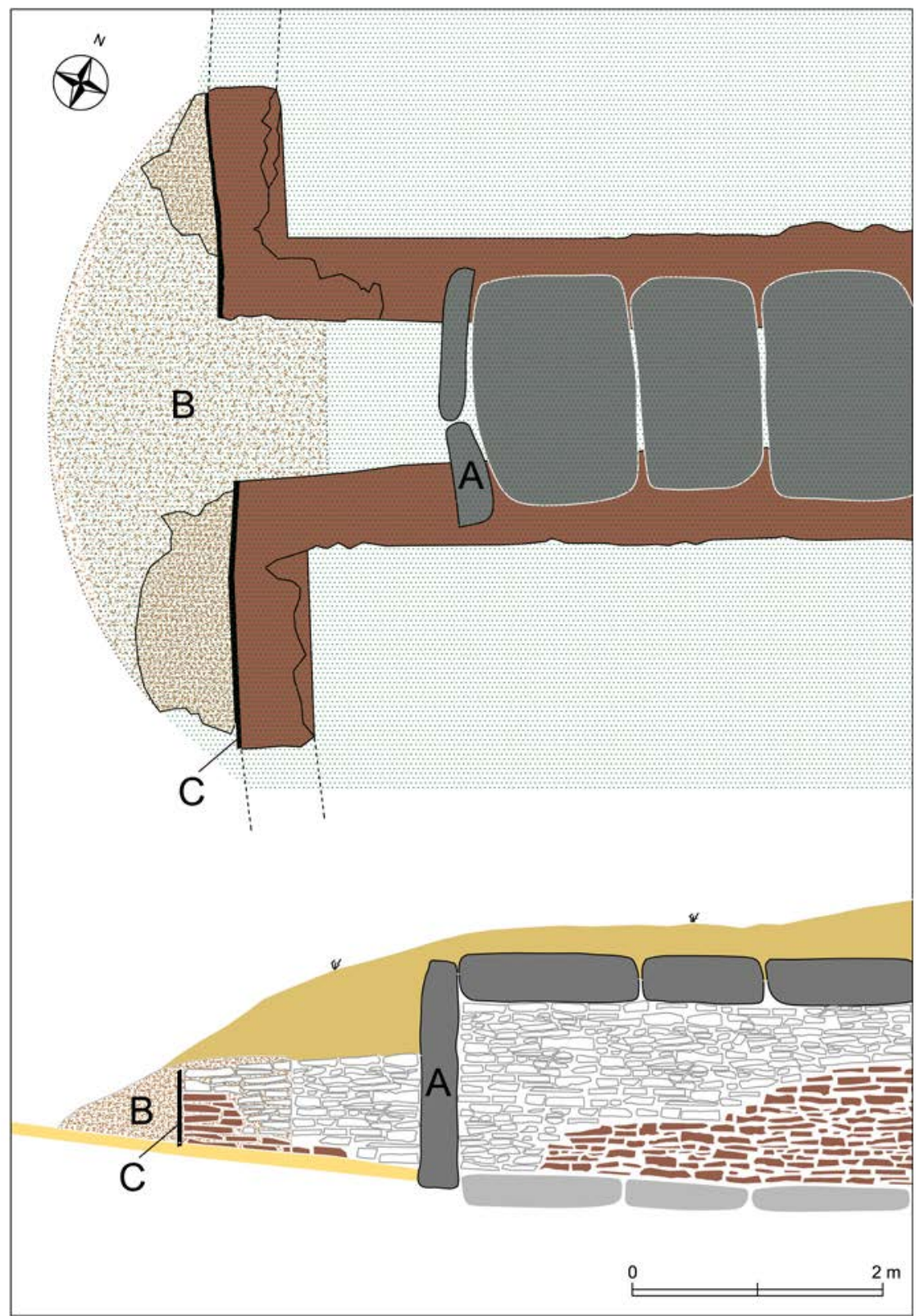

circunstancia en modo alguno es apreciable en los muros. Aunque es esta nuestra mejor opción, analizando otras posibilidades tampoco es descartable que la zanja del norte, sin losa conservada, en vez de dar cobijo a una gran losa vertical que alcanzara a la techumbre, funcionara como un pequeño escalón como el que separa la cámara y corredor en el otro extremo del monumento.

A partir de este punto se aprecia además un sustancial cambio constructivo. En el espacio que resta hasta la fachada, hemos visto cómo pudo existir un cierre interior con dos grandes piedras verticales; no existe ninguna losa de pavimentación conservada, ni parece que nunca la tuviera (Ruiz y Martín 1993: 555); hemos descrito diferencias en los muros laterales que ahora se estrechan y se abren ligeramente -abocinados, hacia el exterior-; y finalmente, es un lugar donde la estratigrafía conservada difiere de la del resto del tramo inicial. Es por tanto, constructiva y arqueológicamente, un ámbito bien diferenciado respecto de la dinámica general de todo el monumento, y si tuviéramos que señalar la presencia de un espacio descubierto a modo de atrio, sería este el que más certeramente pudo cumplir esta 


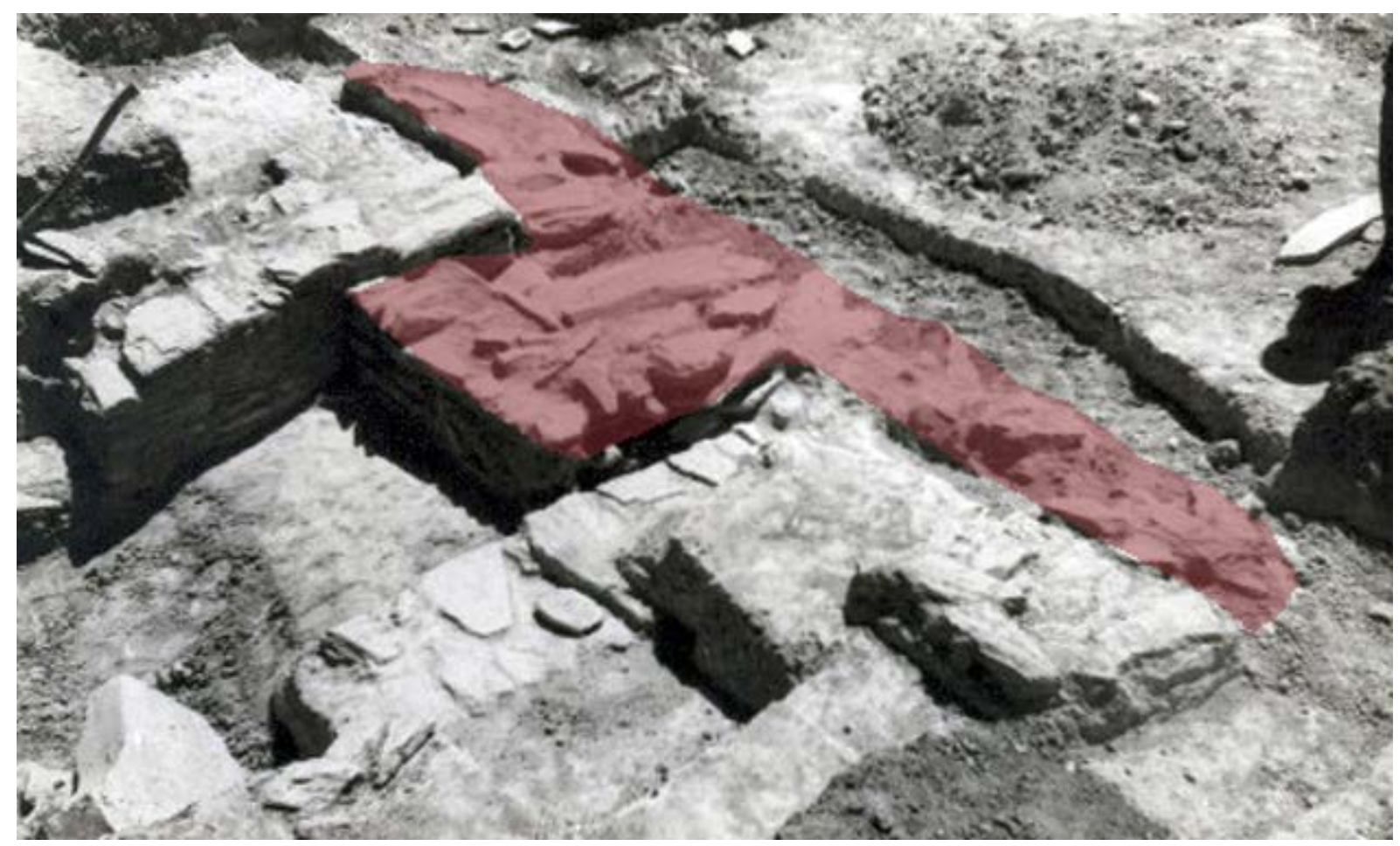

Figura 18. Estructura de taponamiento y clausura definitiva del monumento, imagen de las excavaciones de 1963. Fondo Collantes, caja nº 5, Dpto. de Prehistoria y Arqueología de la Universidad de Sevilla.

función. De modo que durante el uso del tholos permaneció abierto al exterior, para con posterioridad ser clausurado y cegado con el muro interior de taponamiento y los rellenos de tierra excavados en 1991-92 (fig. 17).

Estos últimos elementos (taponamiento y relleno) de la zona inicial del monumento se han postulado como el llamado sello, emplazado en el hueco inicial del corredor y constructivamente separado de la estructura también de mampuestos descrita para la colindante zona exterior (Martín y Ruiz 1995: 418-419, Ruiz 2013: 212-213). Sin embargo, la revisión de las antiguas imágenes de 1963 -especialmente ilustrativa es la reproducida por Fernández Chicarro (1974: 5)- y también las anteriores al desmonte que se realizó en el 1992, más bien señalan una clara continuidad de mampuestos que desde el inicio del corredor (taponándolo) se dirigen hacia fuera sin solución de continuidad y abriéndose hacia los laterales para ocultar la totalidad de los muros (fig. 18). En lo conservado aún hoy se aprecia claramente cómo los restos de esta estructura se disponen ocultando las lajas verticales de revestimiento de la fachada. Es por ello, por lo que creemos que no es posible separar el llamado sello del inicio del corredor de la parte exterior, siendo ambos conformantes de una estructura tipológica y constructivamente homogénea, con pérdidas y lagunas, pero integrantes de una única unidad estructural diseñada para la clausura definitiva del monumento y su premeditado ocultamiento (fig. 17); un evento de inhabilitación del acceso y cierre del tipo registrado en otros monumentos (Tejedor 2014: 78).

En otro orden de cosas, también podemos singularizar cómo dentro de las patologías constructivas, la presencia de abombamientos centrales en el pavimento o las fracturas transversales y oblicuas con continuidad entre bloques que hemos localizado en algunos monolitos de la cubierta, son la respuesta ante un notable esfuerzo estructural y una flexión excesiva de los materiales. En relación con ello, se trata de indicadores que encajan dentro de la tipología de estructuras de deformación que se ha establecido para la clasificación de los efectos arqueológicos de los terremotos (RodríguezPascua et al. 2016: 156, fig. 3), por lo que no podemos descartar que estos daños identificados en la construcción fueran causados por los efectos de las sacudidas de un movimiento sísmico. Es esta una posibilidad que ya se ha apuntado para explicar el colapso de otros monumentos (Tejedor 2014: 82). La evidencia arqueológica de una fractura regularizada, de superficie lisa y con 
patina interior (losa $\left.n^{0} 10\right)$ es indicativa de que la rotura no se ha producido en época reciente (fig. 6).

\section{CONCLUSIÓN}

En definitiva, podemos plantear cómo la edificación correspondiente al tholos de La Pastora se corresponde con una estructura levantada de manera uniforme, sin faseado ni distinciones formales reconocibles, salvo las interfaces identificadas para época reciente.

Se singulariza además de manera más clara y precisa por la situación que presenta el primer tramo de corredor, el peor conservado, pero que supone una pieza clave para interpretar la funcionalidad del monumento y su vigencia temporal, además de ser elemento esencial para despejar la incógnita sobre la restitución general del monumento, especialmente de la zona de entrada original, y también del contexto de aparición de las jabalinas.

Efectivamente, de esta parte proceden los materiales arqueológicos recientemente datados, que junto con las conchas marinas de las losas de la cubierta proporcionan por primera vez una datación absoluta del monumento que supera las realizadas en base al estudio de las jabalinas: 1800-1600 a.C. (Almagro 1962: 34), anterior a la mitad del II milenio a.C. (Montero y Teneishvili 1996: 80), Calcolítico Final (Mederos 2000: 89), III milenio a.C. y transición al II (Hunt et al. 2012: 371), o la formulada con base en su orientación astronómica: 2300-2200 a.C. (Belmonte y Hoskins 2002: 98).

El modelado bayesiano de las dataciones de los bivalvos incrustados en las rocas señalan un momento de entre el 2755-2465 cal a.C. (95\% de probabilidad) 2615-2480 cal a.C. (68\% de probabilidad) a partir del cual se pudo construir el tholos, y un momento final de uso resultante de la cronología de dos restos óseos humanos y una cuenta de concha recuperados en este tramo inicial, que indican una fecha de 2485-1360 cal a.C. (95\% de probabilidad) 2435-2035 cal a.C. (68\% probabilidad) (García Sanjuán et al. 2018: 258-259).

La semejanza de fechas manifiesta el escaso tiempo transcurrido desde la extracción del material para la construcción del monumento, su uso y su definitivo cierre señalado por los contextos de destrucción y relleno de donde proceden las muestras analizadas. Ello supone un argumento para descartar prácticas de enterramientos que incumban a muchas generaciones, lo que además no es discordante con la escasa conservación de vestigios en su interior o con lo documentado en grandes megalitos similares, como Montelirio, donde se ha defendido la simultaneidad de gran parte de los individuos enterrados por el equipo investigador (Bayliss et al. 2016: 493-494).

Los diferentes materiales empleados en su construcción son indicadores de la amplitud del área de captación de recursos, estimable en al menos unos $30 \mathrm{~km}$ alrededor de Valencina. Pero también de su especialización, debido a la singularidad que nos muestran los elementos naturales presentes en las areniscas calcáreas. Ello determina un alto grado de planificación, un excelente conocimiento del medio natural y una especial consideración al menos estética, y quizás simbólica, de las formaciones biogénicas que adornan singularmente todo el interior del edificio, donde como hemos visto, la ausencia de los habituales patrones de decoración de otros megalitos es significativa (Cáceres et al. 2016: 370).

Se trasmite, por tanto, la imagen de un monumental lugar de enterramiento -y también quizás algo más-, levantado, usado y clausurado por un personaje/linaje con capacidad para movilizar recursos procedentes de varias decenas de kilómetros y que en buen número y con carácter diferencial respecto de otros megalitos, se vinculan al mar o más concretamente a la franja costera. De este ámbito proceden las conchas marinas utilizadas como cuentas de collar (Vargas y Sagrera: 2007: 47, fig. 22.6) y del mismo se extrajeron varias toneladas de rocas para levantar su última morada. Puede tratarse de una mera coincidencia, pero desde luego no nos parece descartable, dado el simbolismo que rodea a este tipo de construcciones, la existencia de un interés en resaltar su vinculación con el mar y los recursos que este provee. La presencia en el yacimiento de Valencina de materias primas de origen exótico (marfil, huevos de avestruz o ámbar) está poniendo de manifiesto la relevancia de los intercambios a gran escala y en ello, la primitiva situación del enclave -en el interior, pero al pie mismo del gran entrante de mar- supone un factor geoestratégico de indudable peso. El control de la explotación de estos recursos fue, desde luego, un elemento de progresión económica y social de aquellos individuos que lo detentaran.

\section{Agradecimientos}

Este trabajo se ha desarrollado en el marco del Proyecto de Investigación Geoarqueológica en el Entorno de La Pastora fruto de la colaboración establecida entre el Ayuntamiento de Valencina de la Concepción (Sevilla) y la Consejería de Cultura de la Junta de Andalucía, además del proyecto del MINECO (HAR2017-83474-P). 
Nuestro agradecimiento al Dpto. de Prehistoria y Arqueología de la Universidad de Sevilla que nos facilitó la consulta del Fondo Collantes y a Rubén Parrilla por la colaboración en la elaboración de la figura 4.

\section{BIBLIOGRAFÍA}

Almagro Basch, M. (1962): “El ajuar del dolmen de La Pastora de Valentina del Alcor (Sevilla). Sus paralelos y su cronología”. Trabajos de Prehistoria del Seminario de Historia Primitiva del Hombre: 5-35.

Bayliss, A.; Beavan, N.; Bronk Ramsey, C.; Delgado Huertas, A.; Díaz-Zorita Bonilla, M.; Dunbar, E.; Fernández Flores, A.; García Sanjuán, L.; Hamilton, D.; Mora González, A. y Whittle, A. (2016): "La cronología radiocarbónica del tholos de Montelirio”, A. en Fernández Flores, L. García Sanjuán y M. DíazZorita Bonilla (eds.), Montelirio: un gran monumento megalitico de la Edad del Cobre: 485-502, Sevilla, Consejería de Cultura de la Junta de Andalucía.

Belmonte, J.A. y Hoskin (2002): Reflejo del cosmos. Atlas de arqueoastronomía en el Mediterráneo occidental. Madrid, Equipo Sirius.

Caballero Zoreda, L. (1995): "Método para el análisis estratigráfico de construcciones históricas o lectura de paramentos", Informes de la Construcción 46 (435): 37-46. https://doi.org/10.3989/ic.1995.v46. i435.1096

Cáceres, L.M.; Muñiz, F.; Rodríguez-Vidal, J.; Vargas, J.M. y Donaire, T. (2014): "Marine bioerosion in rocks of the prehistoric tholos of La Pastora (Valencina de la Concepción, Seville, Spain): archaeological and palaeoenvironmental implications”. Journal of Archaeological Science 41: 435-446. https://doi. org/10.1016/j.jas.2013.09.001

Cáceres, L.M.; Vargas, J.M.; Donaire, T.; Muñiz, F. y Rodríguez-Vidal, J. (2016): “Avance del estudio petrográfico de los tholoi de La Pastora y Matarrubilla, Valencina de la Concepción (Sevilla)". Geotemas 16 (2): 367-370.

Candau y Pizarro, F. (1894): Prehistoria de la Provincia de Sevilla. Sevilla, Imprenta de C. Salas.

Cañal y Migolla, C. (1894): Sevilla Prehistórica. Sevilla, Librería de Juan A. Fe.

Carriazo, J.M. (1980): Protohistoria de Sevilla. Sevilla, Ediciones Guadalquivir.

Collantes de Teran, F. (1969): "El dolmen de Matarrubilla”, en Actas del V Symposium Internacional de Prehistoria Peninsular. Tartessos y sus problemas: 47-61. Jerez (1968), Barcelona.
Delibes Castro, G. (2004): "La impronta Cogotas I en los dólmenes de la cuenca del Duero o el mensaje megalítico renovado”. Mainake XXVI: 211-231.

Fernández Chicarro, C. (1964): "Catálogo de la Exposición de Arqueología celebrada en Sevilla con motivo del Congreso", en Actas del VIII Congreso Arqueológico Nacional: 99-113. Sevilla - Málaga (1963), Zaragoza.

Fernández Chicarro, C. (1974): Los dólmenes de Valencina de la Concepción. Sevilla, Publicaciones del Ayuntamiento de Sevilla.

García Sanjuán, L. (2005): “Las piedras de la memoria. La permanencia del megalitismo en el suroeste de la península ibérica durante el II y I milenios ane.”. Trabajos de Prehistoria 62 (1): 85-109. https://doi. org/10.3989/tp.2005.v62.i1.57

García Sanjuán, L. (2008): “Muerte, tiempo, memoria. Los megalitos como memoriales culturales". $\mathrm{PH}$ 67: 34-45.

García Sanjuán, L.; Vargas Jiménez, J.M.; Cáceres Puro, L.M.; Costa Caramé, M.E.; Díaz-Guardamino Uribe, M.; Díaz-Zorita Bonilla, M.; Fernández Flores, A.; Hurtado Pérez, V.; López Aldana, P.M.; Méndez Izquierdo, E.; Pajuelo Pando, A.; Rodríguez Vidal, J.; Wheatley, D.; Bronk Ramsey, C.; Delgado Huertas, A.; Dunbar, E.; Mora González A.; Bayliss, A.; Beavan, N.; Hamilton D. y Whittle, A. (2018): "Assembling the Dead, Gathering the Living: Radiocarbon Dating and Bayesian Modelling for Copper Age Valencina de la Concepcion (Seville, Spain)". Journal World Prehistory 31: 179-313. https://doi.org/10.1007/s10963018-9114-2

Gestoso y Pérez, J. (1889): Sevilla monumental y artística. Sevilla, Edición facsímil del Monte de Piedad y Caja de Ahorros de Sevilla.

Gómez de Terreros Guardiola, M. G. (2005): Intervenciones en Dólmenes, 1953-1964. Proyectos y Obras de Félix Hernández Giménez. Dólmenes de Matarrubilla y Cueva de la Pastora. (Valencina de la Concepción, Sevilla). Dolmen de Zancarrón de Soto (Trigueros, Huelva). Sevilla, Universidad de Sevilla.

Hunt Ortiz, M. A.; Martínez Navarrete, M. I.; Hurtado Pérez V. y Montero Ruiz, I. (2012): "Procedencia de las puntas de jabalina del "Dolmen de La Pastora" (Valencina de la Concepción, Sevilla)". Trabajos de Prehistoria 69 (2): 357-374. https://doi. org/10.3989/tp.2012.12097

Laporte, L. y Scarre, C. (eds.) (2016). The megalithic architectures of Europe, Oxbow Books. 
Leisner, G. und V. (1943): Die Megalithgräber der Iberischen Halbinsel. Erster Teil: Der Suden. Römisch-Germanische Forschungen 17. (Röm-German. Komm. d. Deutsch. Arch. Inst. zu Frankfurt a. M.). Berlín, Verlag von Walter de Gruyter.

Martín Espinosa, A. y Ruiz Moreno, M. T. (1995): “Excavación en el dolmen de La Pastora (Valencina de la Concepción, Sevilla). Revisión y actualización de las investigaciones.", en Actas del XXII Congreso Nacional de Arqueología. Tomo I: 417-420, Vigo (1993), Vigo, Xunta de Galicia.

Mederos Martín, A. (2000): "Puntas de jabalina de Valencina de la Concepción (Sevilla) y del área palestino-israelita”. Madrider Mitteilungen 41: 83-111.

Montero Ruiz, I. y Teneishvili, T. O. (1996): "Estudio actualizado de las puntas de jabalina del Dolmen de la Pastora (Valencina de la Concepción, Sevilla)”. Trabajos de Prehistoria 53 (1): 73-90.

Murillo Díaz, M.T.; Pérez Revuelta, C.; Blanco Ruíz, C. y Larrey Hoyuelos E. (1987): “Excavación en el yacimiento calcolítico del polideportivo de Valencina de la Concepción (Sevilla), 1985”. Anuario Arqueológico de Andalucía/1985 Tomo III: 311-315.

Obermaier, H. (1919): El Dolmen de Matarrubilla (Sevilla). Memorias de la Comisión de Investigaciones Paleontológicas y Prehistóricas 26. Madrid, Museo de Ciencias Naturales.

Ortega Gordillo, M. (2013): "El registro estratigráfico en el pabellón cubierto de Valencina de la Concepción (Sevilla)”, en L. García-Sanjuan, J.M. Vargas Jiménez, V. Hurtado Pérez, T. Ruiz Moreno y R. Cruz-Auñón Briones (eds.), El Asentamiento Prehistórico de Valencina de la Concepción (Sevilla): Investigación y Tutela en el 150 Aniversario del Descubrimiento de La Pastora: 113-130, Sevilla, Universidad de Sevilla.

Parenti, R. (1988): "Sulle possibilità di datazione e di classificazione delle murature", en Archeologia e restauro dei monumenti: 280-304. Firenze.

Pizzo A. (2009): "La arqueología de la construcción. Un laboratorio para el análisis de la arquitectura de época romana”. Arqueología de la Arquitectura 6: 31-45. https://doi.org/10.3989/arqarqt.2009.09001

Rodríguez-Pascua, M.A.; Silva, P.G.; Giner Robles, J.L.; Pérez López, R.; Perucha, M.A. y Marín González, F. (2016): “Arqueosismología: una nueva herramienta para la sismología y la protección del patrimonio”. Revista Otarq 1: 151-169.

Ruiz Moreno, M. T. (2013): "La Pastora (Valencina de la Concepción, Sevilla): una historia desconocida”, en L. García-Sanjuan, J.M. Vargas Jiménez, V. Hurtado Pérez, T. Ruiz Moreno y R. Cruz-Auñón Briones (eds.), El Asentamiento Prehistórico de Valencina de la Concepción (Sevilla): Investigación y Tutela en el 150 Aniversario del Descubrimiento de La Pastora: 201-217. Sevilla, Universidad de Sevilla.

Ruiz Moreno, M. T. y Martín Espinosa, A. (1993): “Excavación de urgencia en el dolmen de La Pastora, Valencina de la Concepción, Sevilla.” Anuario Arqueológico de Andalucía/1991: 554-558.

Siret, L. (1913): Questions de chronologie et d'ethnographie ibériques. I. De la fin du Quaternaire à la fin du Bronze. Paris, Paul Geuthner.

Tabales M.A. (1997): “Análisis arqueológico de paramentos. Aplicaciones en el patrimonio edificado sevillano”. Spal 6: 263-295. http://dx.doi. org/10.12795/spal.1997.i6.15

Tejedor Rodríguez, C. (2014): “Reconstruyendo “biografías megalíticas”: algunos ejemplos de alteraciones estructurales en monumentos megalíticos del valle del Duero/Douro", en Investigaciones Arqueológicas en el valle del Duero: Del Neolítico a la Antigüedad Tardía. Actas de las Segundas Jornadas de Jóvenes Investigadores del valle del Duero: 67-86. Glyphos Publicaciones.

Tubino y Oliva, F. M. (1868): "Monumento Prehistórico de Castilleja de Guzmán”. Gaceta de Madrid 23 de Marzo 1868. Madrid.

Vargas Jiménez, J.M. (2004): Carta Arqueológica Municipal de Valencina de la Concepción. Sevilla, Junta de Andalucía, Consejería de Cultura.

Vargas Jiménez, J.M. y Sagrera Pérez M.I. (2007): El Museo de Valencina, Monográfico del Yacimiento Prehistórico. Una infraestructura para la difusión cultural. Sevilla, Fundación Cajasol.

Vargas Jiménez, J.M.; Meyer, C. y Ortega Gordillo, M. (2012): "El tholos de La Pastora y su entorno: el sector oriental del yacimiento de Valencina de la Concepción (Sevilla) a través de la geofísica”. Menga, Revista de Prehistoria de Andalucía 3: 121-138.

Vargas Jiménez, J.M.; Cáceres Puro, L.M.; Rodríguez Vidal, J.; Donaire Romero, T. y Muñiz Guinea, F. (2019): "Monumental sector in the archaeological site of Valencina de la Concepción (Seville): Research in the area from La Pastora”, en J. Müller y M. Hinz (eds.), Megaliths, societies, landscapes: Early monumentality and social differentiation in Neolithic Europe: 367-388, Kiel, University of Kiel. 